EFFECTS OF AGRICULTURE ON QUALITY OF WATER IN SURFICIAL SAND-PLAIN AQUIFERS IN DOUGLAS, KANDIYOHI, POPE, AND STEARNS COUNTIES, MINNESOTA

By H. W. Anderson, Jr.

U.S. GEOLOGICAL SURVEY

Water-Resources Investigations Report 87-4040

Prepared in cooperation with the

SOIL AND WATER CONSERVATION DISTRICTS OF DOUGLAS, KANDIYOHI, POPE, AND STEARNS COUNTIES, and the WESMIN RESOURCE CONSERVATION AND DEVELOPMENT ASSOCIATION

St. Paul, Minnesota

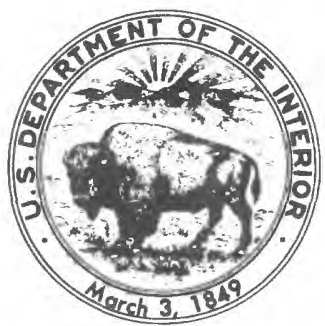

1989 


\section{DEPARTMENT OF THE INTERIOR}

MANUEL LUJAN, JR., Secretary

U.S. GEOLOGICAL SURVEY

Dallas L. Peck, Director

For additional information write to:

District Chief U.S. Geological Survey 702 Post Office Building

St. Paul, Minnesota 55101
Copies of this report can be purchased from:

U.S. Geological Survey Books and Open-File Reports Section Federal Center, Building 41 Box 25425

Denver, Colorado 80225 


\section{CONTENTS}

Page

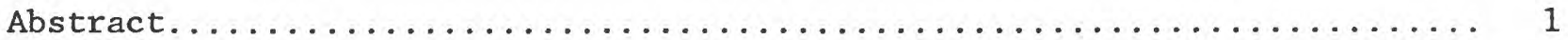

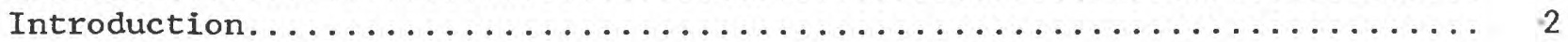



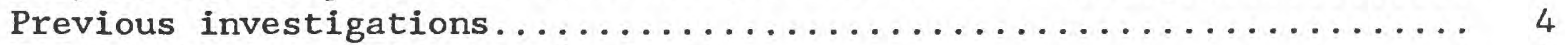

Hydrogeologic setting and land use.................... 5

Hydrologic properties of surficial aquifers................ 5

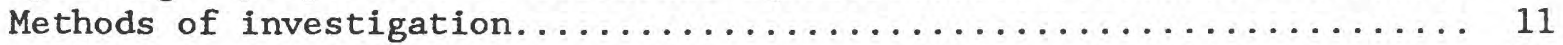

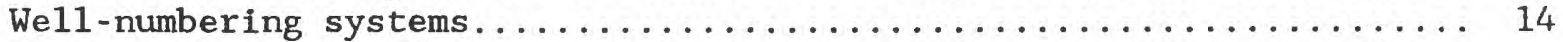

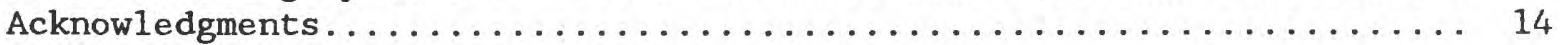

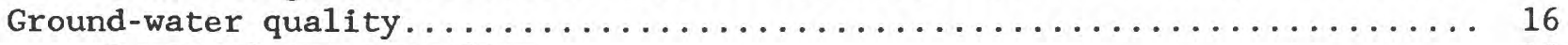

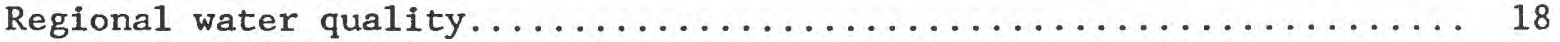

Vertical distribution of water-quality constituents ........... 22

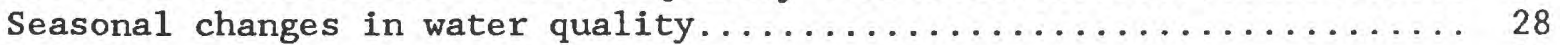

Long-term changes in water quality.................... 34

Effects of agriculture on quality of water in sand-plain aquifers...... 42

Relation of water quality to land use...................... 42

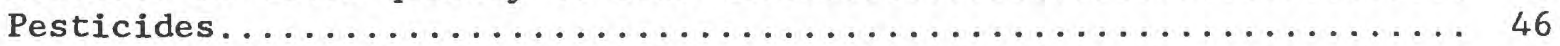

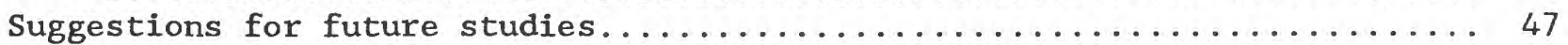

Conclusions....................................... 49

References cited................................. 51

\section{ILLUSTRATIONS}

Figures 1-3. Maps showing:

1. Water-quality studies in surficial sand-plain areas of

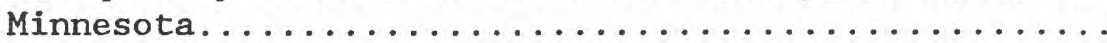

2. Areal extent of surficial sand-plain aquifers and approximate location of wells sampled in Douglas, Kandiyohi, Pope, and Stearns Counties, Minnesota....

3. Generalized water table of the sand-plain aquifers in Douglas, Kandiyohi, Pope, and western Stearns



4. Hydrograph of water levels showing annual and long-term fluctuations in we11 129N36W18CBB01, Douglas County,

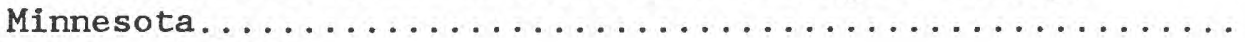

5-6. Diagrams showing:

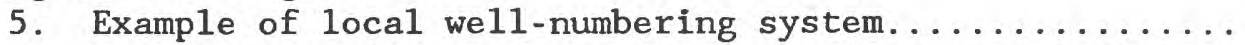

6. Generalized effect of topographic relief on the flow of



7-8. Graphs showing seasonal fluctuations in:

7. Water levels and concentrations of nitrite plus nitrate nitrogen at two well sites in the Sauk River valley,



8. Nitrite plus nitrate nitrogen concentrations in wells in irrigated areas in the Viking Basin, Douglas County and the Bonanza Valley, Pope County, Minnesota. 


\section{ILLUSTRATIONS - - continued}

Page

Figures 9-11. Graphs showing seasonal fluctuations in concentrations of:

9. Sulfate and chloride at two well sites in the Sauk

River valley, Stearns County, Minnesota..........

10. Iron at two well sites in the Sauk River valley,



11. Manganese at two well sites in the Sauk River valley,



12-15. Graphs showing historical trends in nitrite plus nitrate nitrogen concentrations in wells:

12. Less than 10 feet below the water table in uncultivated and nonirrigated cultivated

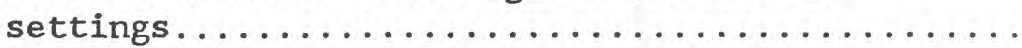

13. From 10 to 20 feet below the water table in nonirrigated cultivated settings........... 39

14. Completed from 10 to 20 feet below the water table in irrigated settings................ 40

15. Screened more than 20 feet below the water table in

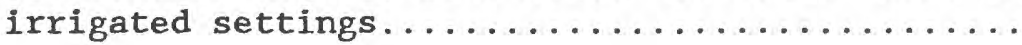

\section{TABLES}

Table 1. Minnesota standards for drinking water, and number of samples



2. Statistical summary of 43 baseline chemical analyses of water from surficial sand-plain aquifers in Douglas, Kandiyohi, Pope, and Stearns Counties, west-central Minnesota, in fall 1982 and spring $1983 \ldots \ldots \ldots \ldots \ldots \ldots \ldots$

3. Mean and median concentrations for selected constituents in the

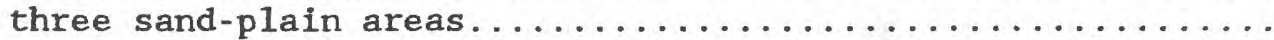

4. Water quality at various depths below the water table in Douglas, Kandiyohi, Pope, and Stearns Counties, Minnesota....

5. Range of nitrite plus nitrate nitrogen concentrations in water-

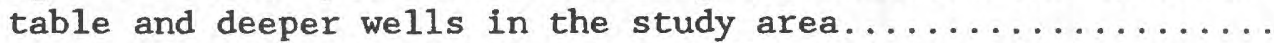

6. Summary of seasonal water-quality analyses for sand-plainaquifer wells sampled for nitrite plus nitrate nitrogen at least four times during 1983 in Douglas, Kandiyohi, Pope,

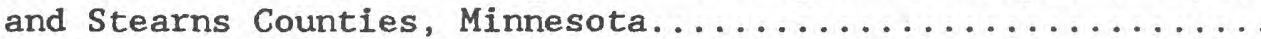



8. Nitrite plus nitrate nitrogen concentrations in wells completed at different depths below the water table in various land-use

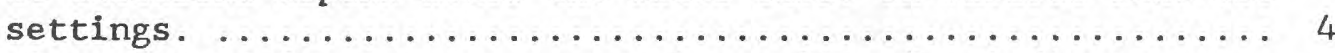

9. Wells selected for long-term annual sampling for indicator

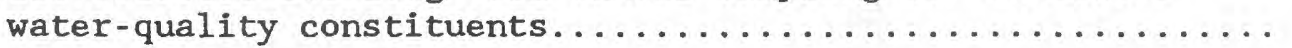




\section{CONVERSION FACTORS AND ABBREVIATIONS}

Readers who prefer to use metric (International System) units rather than inch-pound units can make conversions using the following factors:

Multiply Inch-Pound Unit

inch (in)

foot $(f t)$

foot per day ( $\mathrm{ft} / \mathrm{d})$

foot squared per day $\left(f t^{2} / d\right)$

cubic foot $\left(\mathrm{ft}^{3}\right)$

gallon (gal)

gallon per minute (gal/min)

$\operatorname{mile}(\mathrm{mi})$

million gallons per year (Mgal/yr)

$\frac{\text { By }}{25.4}=$

0.3048

0.09290

0.02832

0.003785

0.06308

1.609

3,785
To Obtain Metric Unit

millimeter (mm)

meter (m)

meter per day (m/d)

meter squared per day $\left(\mathrm{m}^{2} / \mathrm{d}\right)$

cubic meter $\left(\mathrm{m}^{3}\right)$

cubic meter $\left(\mathrm{m}^{3}\right)$

1iters per second (L/s)

kilometer $(\mathrm{km})$

cubic meters per year $\left(\mathrm{m}^{3} / \mathrm{yr}\right)$

Temperature in degrees Fahrenheit $\left({ }^{\circ} \mathrm{F}\right)$ can be converted to degrees Celsius $\left({ }^{\circ} \mathrm{C}\right)$ as follows: ${ }^{\mathrm{o}} \mathrm{F}=1.8{ }^{\circ} \mathrm{C}+32$

Sea leve1: In this report "sea leve1" refers to the National Geodetic Vertical Datum of 1929 (NGVD of 1929)--a geodetic datum derived from a general adjustment of the first-order level nets of both the United States and Canada, formerly call "Sea Level Datum of 1929." 


\title{
EFFECTS OF AGRICULTURE ON QUALITY OF WATER IN SURFICIAL SAND-PLAIN AQUIFERS IN DOUGLAS, RANDIYOHI, POPE, AND STEARNS COUNTIES, MINNESOTA
}

\author{
By H. W. Anderson, Jr.
}

\section{ABSTRACT}

The 245 water samples collected from 56 wells at 45 sites in surficial sand-plain aquifers that underlie 600 square miles of Douglas, Kandiyohi, Pope, and Stearns Counties in west-central Minnesota contained wide ranges in concentrations of some constituents--sulfate 2 to $160 \mathrm{mg} / \mathrm{L}$ (milligrams per liter), chloride 1.6 to $64 \mathrm{mg} / \mathrm{L}$, nitrite plus nitrate nitrogen < (less than) 0.1 to $72 \mathrm{mg} / \mathrm{L}$, ammonia $<0.01$ to $3.3 \mathrm{mg} / \mathrm{L}$, iron $<0.003$ to $8.6 \mathrm{mg} / \mathrm{L}$, and managanese $<0.001$ to $1.5 \mathrm{mg} / \mathrm{L}$. Substantial fluctuations in these constituents over time were observed. Nitrate concentrations exceeded the Minnesota drinking-water standard of $10 \mathrm{mg} / \mathrm{L}$ (as $\mathrm{N}$ ) in 50 percent of the wells sampled.

Differences in concentrations of nitrate with depth below the water table were observed at 11 paired-well sites where one well was screened near the water table and another well was screened 10 or more feet below the water table. Similar differences in concentration with depth were observed in specific conductance, iron, chloride, and sulfate, but not as consistently. At eight sites, nitrate concentrations were higher at the water table ( 4.3 to $72 \mathrm{mg} / \mathrm{L}$ ) than deeper in the aquifer $(<0.1$ to $27 \mathrm{mg} / \mathrm{L})$. At the other three sites, nitrate concentrations were greater at depth than at the water table, although the contrast in concentrations was not as large. Increased concentration at depth is attributed to vertical mixing at the three sites, possibly caused by rapid infiltration of more dilute water from ephemeral ponds following storms. The more dilute water displaces the high-nitrate water to greater depth.

Nitrate concentrations fluctuated seasonally in response to the combined effects of precipitation and agricultural practices (irrigation and fertilization). Nitrite plus nitrate nitrogen concentrations in one Stearns County well fluctuated from $35 \mathrm{mg} / \mathrm{L}$ in August 1982 , to $72 \mathrm{mg} / \mathrm{L}$ in May 1983, to $18 \mathrm{mg} / \mathrm{L}$ in May 1984. In 12 wells for which historical data were available, the mean nitrate concentration during this study (1982-84) was greater than the mean concentration during previous studies (1965-78), although the amount of increase in nitrate concentrations observed over the previous 10 or more years was not as great as the seasonal fluctuations observed during this study. Short-term seasonal fluctuations are greater than apparent historical increases in nitrate concentration.

Concentrations of sulfate, chloride, and, especially, nitrate were significantly higher in irrigated areas than in uncultivated areas. Mean nitrite plus nitrate nitrogen concentrations were $4.3 \mathrm{mg} / \mathrm{L}$ in uncultivated (natural) areas relatively unaffected by agriculture, $5.4 \mathrm{mg} / \mathrm{L}$ in nonirrigated cultivated areas, and $17 \mathrm{mg} / \mathrm{L}$ in irrigated cultivated areas. The mean nitrite plus nitrate nitrogen concentration in uncultivated areas was greater than the usually observed background levels of less than $1 \mathrm{mg} / \mathrm{L}$ (as nitrogen), which may indicate that areas thought to be natural actually are affected by agricultural land use. Several statistical tests indicate that nitrate 
concentrations are significantly higher in irrigated cultivated areas than in nonirrigated cultivated areas. The difference in nitrate concentrations between irrigated and nonirrigated areas suggests that nitrate from agricultural fertilizer is being leached during heavy rainfall or irrigation periods as a result of higher concentrations of nitrogen being maintained in the soil to enhance yields of corn and potatoes.

Four of eight wells sampled for herbicides in west-central Minnesota had detectable concentrations of the triazine herbicide atrazine that ranged from 0.2 to 0.6 micrograms per 1iter. These concentrations were well below the water-quality guidelines published by the Canadian Inland Waters Directorate, Water Quality Branch, which specify 100 micrograms per 1 iter as the maximum permissible concentration for the group of triazine herbicides in a raw drinking-water supply.

\section{INTRODUCTION}

In recent years, State and local agencies in Minnesota have become concerned about possible degradation of ground-water quality as a result of some agricultural practices, particularly in the large sand plains of central and western Minnesota where crop irrigation has increased dramatically. Surficial-sand aquifers that underlie the sand plains are used extensively for water supplies but are particularly susceptible to contamination from land surface. Soil and Water Conservation Districts (SWCD's) need more information on the effects of agricultural chemicals, fertilizers and pesticides, on ground-water quality, to manage ground-water resources effectively. To address these concerns, a series of water-quality studies is underway in the sand-plain areas of Minnesota (fig. 1). The U.S. Geological Survey, in cooperation with the SWCD's in Douglas, Kandiyohi, Pope, and Stearns Counties, Minnesota, collected 245 ground-water samples in a sand-plain area of about $600 \mathrm{mi}^{2}$. The study encompassed areas known locally as the Bonanza Valley in Pope, Stearns, and Kandiyohi Counties, the southern part of the Viking Basin in Douglas County, and the Sauk River valley in western Stearns County.

\section{Purpose and Scope}

This report describes: (1) the areal and seasonal variation in water quality in the surficial sand-plain aquifers in relation to agricultural practices, (2) vertical mixing in the aquifer downgradient from irrigated areas, (3) long-term changes in water quality by comparison of results from current and previous chemical analyses, (4) baseline water-quality data for use in future assessments of long-term trends and effects on water quality of the use of agricultural fertilizers and pesticides, and (5) a group of wells that may be incorporated into a state-operated network for long-term monitoring of water quality. 


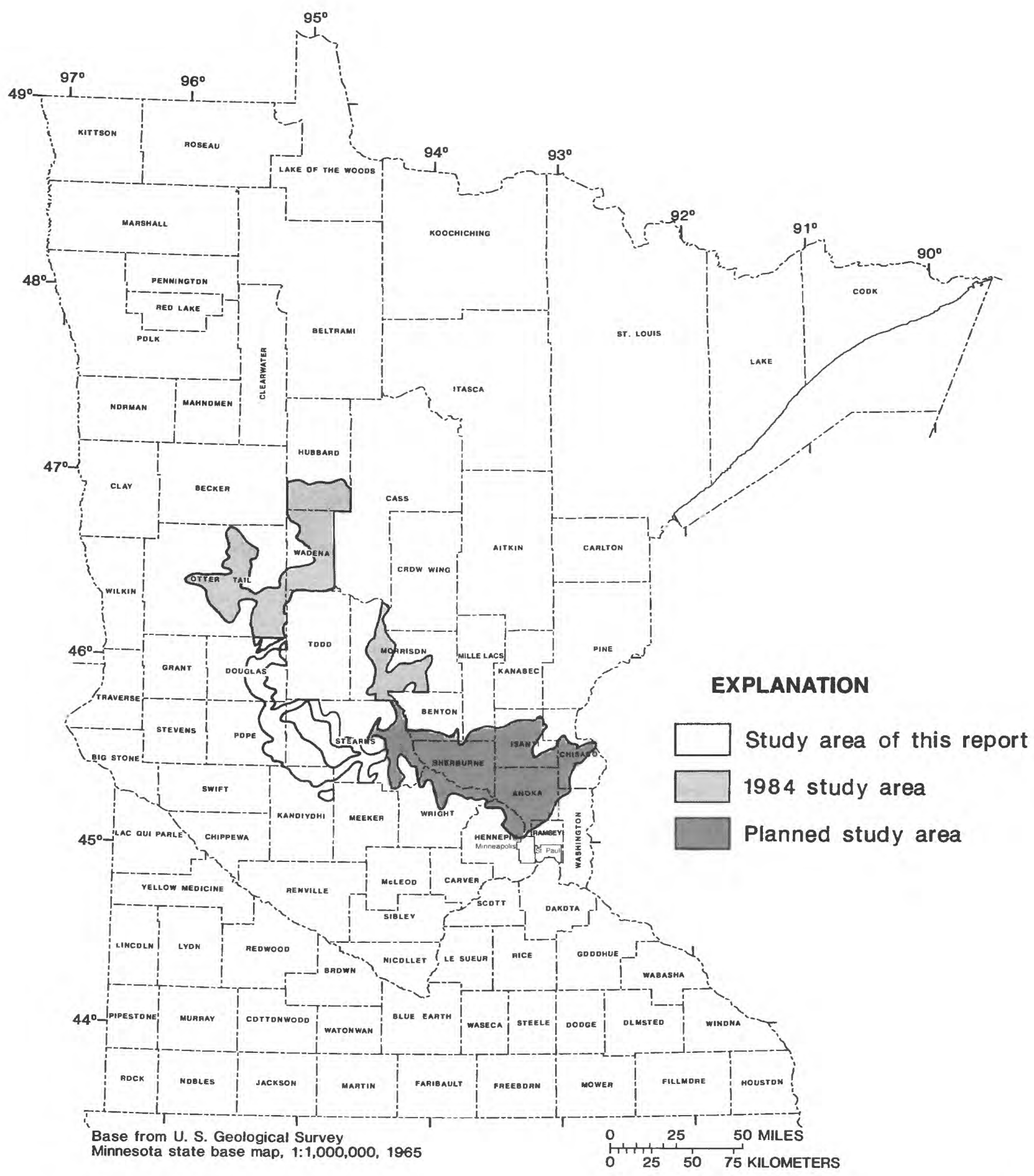

Figure 1.--Water-quality studies in surficial sand-plain areas of Minnesota. 
The 245 water samples collected from 56 wells at 45 sites represent ground water quality in surficial sand-plain aquifers that underlie 600 square miles of Douglas, Kandiyohi, Pope, and Stearns Counties in west-central Minnesota. This report relates the observed water quality to local agriculture, irrigated or nonirrigated. Wells sampled were selected in locations representing the maximum effect of land use, irrigated or nonirrigated agriculture and "natural" undeveloped areas. One sample from each well was analyzed for major and minor ions, nutrients, and dissolved organic carbon. Select wells were resampled several times for sulfate, chloride, nitrite plus nitrate nitrogen, and ammonia. These constituents fluctuate more than others and were resampled to determine if they might be related to agriculture. Special emphasis is given to the effect of agriculture on nitrate concentrations in ground water because (1) previous investigations, including Myette (1984) indicate that agricultural areas contribute significant amounts of nitrate to ground water and (2) nitrate exceeds the Federal (U.S. Environmental Protection Agency, 1977, P. 107) and State (Minnesota Pollution Control Agency, 1978, p. 12) recommended limit for drinking water in many wells.

\section{Previous Investigations}

The design of this study was based on results of previous ground-water studies in the area. Use of ground water from the surficial sand-plain aquifer for irrigation in the Brooten-Belgrade area (locally referred to as the Bonanza Valley) was described by Van Voast (1971). Calcium, magnesium, and bicarbonates were the major ions present. He noted that increased sulfate, chloride, and nitrate indicate possible contamination from barnyards, feedlots, or domestic sewage and expressed concern that irrigation and increased use of fertilizers might increase nitrate concentrations in the ground water. He also indicated that high nitrate concentrations are not necessarily caused by irrigation.

In the Viking Basin in Douglas County, McBride (1975) made observations similar to Van Voast's and also noted elevated concentrations of iron and manganese in the ground water. He also suggested that agricultural areas may be a source of seepage from feedlots and of contamination from agricultural chemicals (herbicides and insecticides). Lindholm (1980, p. 91) studied four counties near St. Cloud, Minnesota, and noted a general increase in the concentration of total organic carbon between 1969 and 1978 in intensively farmed areas in Stearns County. He found that nitrate and chloride concentrations in ground water were highest in the area between the Elk and Mississippi Rivers in Sherburne County. In 1977 and 1978, nitrate nitrogen concentrations were as high as $23 \mathrm{mg} / \mathrm{L}$ (milligrams per liter) and concentrations of chloride were as high as $41 \mathrm{mg} / \mathrm{L}$.

Myette (1984) determined baseline ground-water quality in sand-plain aquifers in Hubbard, Morrison, Otter Tail, and Wadena Counties, Minnesota. He evaluated long-term trends, and investigated seasonal variations in concentrations of selected chemical constituents in the ground water based on water samples collected periodically from 124 wells in the four-county area (fig. 1). In addition to the study by Myette (1984) and the present study 
of water quality in surficial sand-plain aquifers in west-central Minnesota, a third study of the effect of land use on water quality in the Anoka sand-plain aquifer ( $f i g$. 1) was begun in July 1983.

\section{Hydrogeologic Setting and Land Use}

Surficial deposits in most of the project area are composed of glacial outwash, which generally is less than 60 feet thick but locally is more than 100 feet thick (Van Voast, 1971; McBride, 1975). The outwash is made up of cross-bedded sand and gravel that is interbedded in places with silt and clay. The outwash is of Quaternary age and was deposited about 10,000 to 15,000 years ago (Wright and Ruhe, 1965, p. 34).

The Bonanza Valley aquifer (fig. 2) in Kandiyohi, Pope, and Stearns Counties is as much as 10 miles wide and almost 40 miles long; it underlies an area of about $300 \mathrm{mi}^{2}$ (square miles). In the Bonanza Valley, Van Voast (1971) described glacial drift of Quaternary age as much as 300 feet thick underlain by crystalline rocks of Precambrian age or by sedimentary rocks of Cretaceous age. In 1984, about 45,000 acres of cultivated land was irrigated, which represents about 25 percent of the Bonanza Valley.

The Viking Basin aquifer (fig. 2) in Douglas County is about 4 to 6 miles wide and underlies an area of about $140 \mathrm{mi}^{2}$. In the Viking Basin, the glacial drift is from 300 to 400 feet thick and is underlain by igneous and metamorphic rocks (McBride, 1975, p. 8). In 1984, about 4,000 acres of cultivated land was irrigated. Most of the irrigated acreage is northeast of the city of Alexandria, but some is southeast of Alexandria. The northern and western parts of the Viking Basin have little agricultural development, because the terrain is hilly.

Outwash aquifers along the Sauk River valley in western Stearns County and the Crow River Valley in Kandiyohi County are narrow compared to the Bonanza Valley and Viking Basin; they are only a mile or two wide. Outwash in the Sauk River valley in Stearns County is nearly 50 percent poorly sorted gravel that is irregular in thickness (Lindholm, 1980, p. 1). The aquifers have been developed locally for irrigation supplies.

\section{Hydrologic Properties of Surficial Aquifers}

The saturated thickness of the surficial sand-plain aquifer in the Bonanza Valley (fig. 2) ranges from less than 10 feet along the northern and northeastern boundaries to approximately 60 feet along the southwestern boundary (Van Voast, 1971, p. E12). In the Viking Basin, the saturated thickness of the Carlos outwash (fig. 3) is about 40 feet in a third of the area (McBride, 1975, p. 10) and, in the southern part of the Alexandria outwash, generally is about 30 feet. Saturated thickness is as much as 80 feet in the northern part of the Alexandria outwash, and much of this area is urbanized (McBride, 1975, p. 23). In the southern tip of the Parker's Prairie outwash in northern Douglas County, saturated thickness generally is less than 40 feet (McBride, 1975, fig. 8). In the sand plains along the Sauk River in western Stearns County, saturated thickness generally is less than 40 feet; locally it is about 80 feet (Lindholm, 1980, p1. 2). 


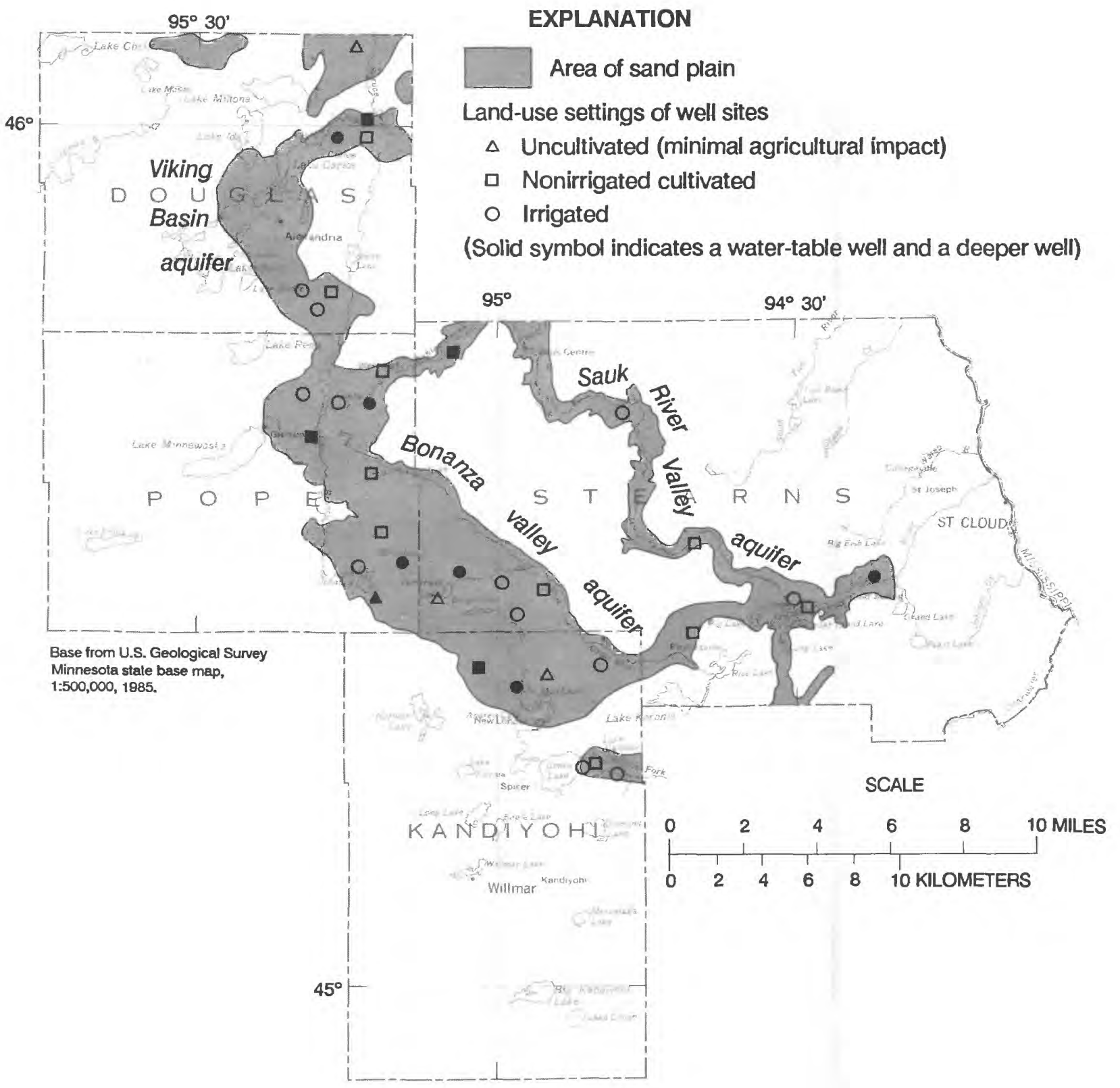

FIGURE 2.--Areal extent of surficial sand-plain aquifers and approximate location of wells sampled in Douglas, Kandiyohi, Pope, and Stearns Counties, Minnesota. 
The depth from land surface to the water table in the study area ranges from 0 to about 30 feet. The major source of recharge to the aquifer is precipitation that infiltrates the soil and percolates to the water table. The very sandy soil of the sand plains allows rapid infiltration of precipitation and, thus, rapid transport of dissolved minerals from the soil to the water table.

Ground water moves laterally through the surficial sand-plain aquifers following the water-table gradients shown in figure 3. Major ground-water divides in the sand-plain aquifers correspond to surface-drainage divides, so that the direction of ground-water flow may be inferred from the land slope. Most of the ground water not lost by evapotranspiration from a shallow water table or by pumpage is discharged to surface-water bodies (lakes and streams). Less than 6 percent of the 7,380 Mgal/yr (million gallons per year) pumped for irrigation in Douglas, Kandiyohi, Pope and Stearns Counties is from surface water.

In the study area, more ground water is used for irrigation than for any other purpose. Estimated municipal water use in 1980 for the four-county area was 3,000 Mgal/yr. Estimated municipal water use from just the sand-plain aquifer area in 1980 was $850 \mathrm{Mgal} / \mathrm{yr}$ (unpublished data, U.S. Geological Survey). Pumpage for irrigation by 504 permit holders in the four-county area was 7,380 Mgal/yr in 1983 (Gina Miller, Minnesota Department of Natural Resources, written commun., 1985), more than twice as much as municipal water use for the entire four counties and most of the irrigation is in the sandplain area.

Ground-water movement in the Bonanza Valley is toward the southeast and east. In the Viking Basin, ground water in the Carlos outwash area converges on the local rivers and regionally moves eastward. In the southern part of the Alexandria outwash area, ground water generally moves eastward. In the southern tip of the Parkers Prairie outwash area (fig. 3), ground water converges on local creeks and regionally moves southward. In northwestern Stearns County and along the Sauk River sand plain, ground water locally moves toward the river and regionally moves toward the southeast.

Hydraulic conductivity and transmissivity are indicators of an aquifer's ability to transmit water through the ground-water system and yield water to wells. Most sand and gravel deposits in the study area have a hydraulic conductivity in the range from 100 to about $300 \mathrm{ft} / \mathrm{d}$ (feet per day) (Van Voast, 1971, p. E12). In the Bonanza Valley, transmissivity generally ranges from 0 to about $4,000 \mathrm{ft}^{2} / \mathrm{d}$ (feet squared per day); locally it is as much as $8,000 \mathrm{ft}^{2} / \mathrm{d}$. The theoretical optimum yield to wells generally is about 300 gal/min (gallons per minutes), but locally some wells yield as much as 1,000 gal/min. In the Viking Basin (McBride, 1975, p. 12-16), transmissivity locally is as much as $20,000 \mathrm{ft}^{2} / \mathrm{d}$. The theoretical optimum yield to wells locally is as much as $2,500 \mathrm{gal} / \mathrm{min}$ in the Carlos outwash and as much as 1,000 gal/min in the Alexandria outwash and the Parkers Prairie outwash. The Sauk River valley outwash in Stearns County has a transmissivity generally less than $5,000 \mathrm{ft}^{2} / \mathrm{d}$. Locally, however, transmissivity ranges from 10,000 to $20,000 \mathrm{ft}^{2} / \mathrm{d}$, and theoretical optimum weil yields are about $1,000 \mathrm{gal} / \mathrm{min}$. 

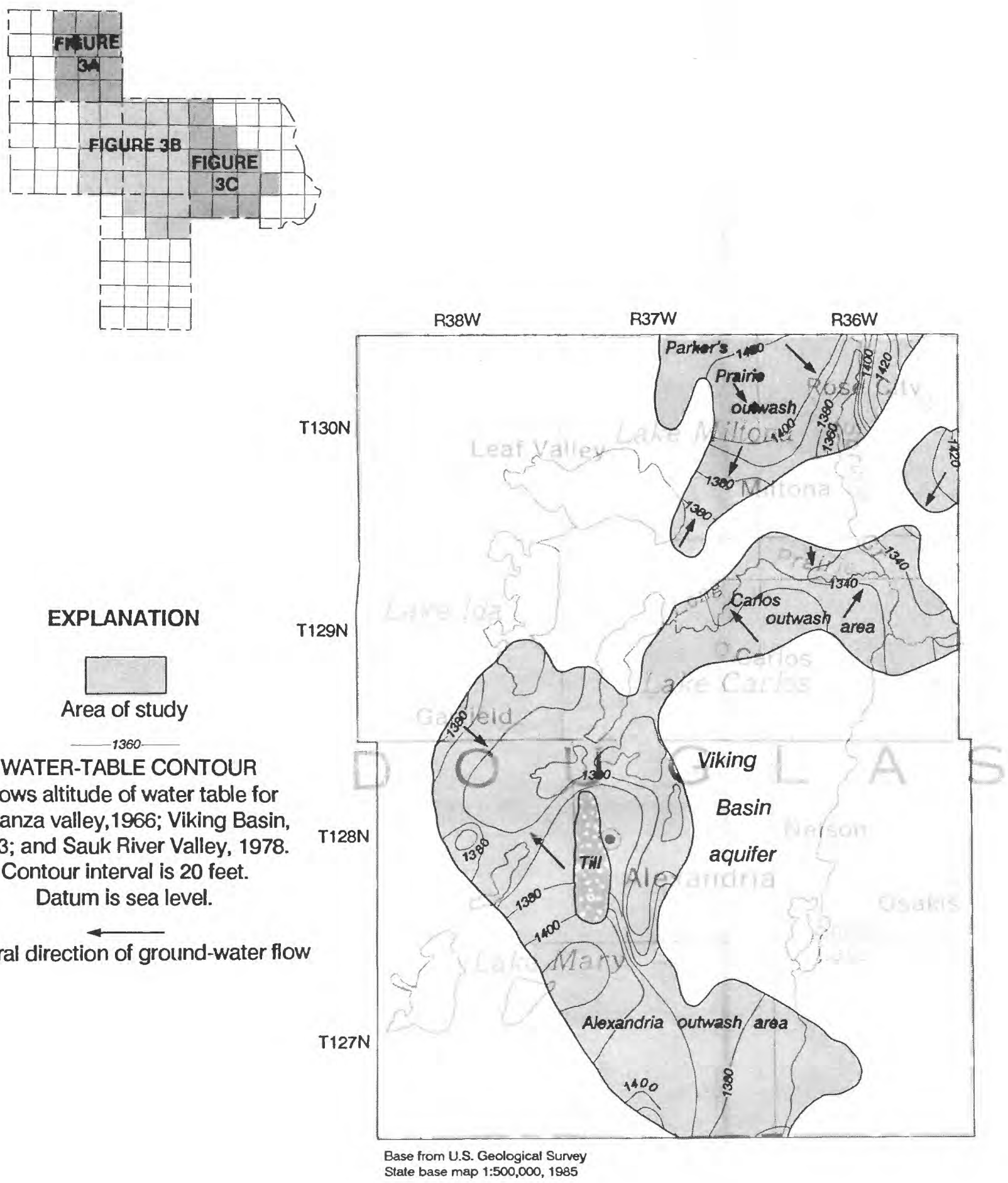

EXPLANATION

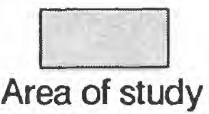

WATER-TABLE CONTOUR

Shows altitude of water table for Bonanza valley,1966; Viking Basin, 1973; and Sauk River Valley, 1978. Contour interval is 20 feet.

Datum is sea level.

General direction of ground-water flow

State base map $1: 500,000,1985$

SCALE

$\begin{array}{llllllll}0 & & 2 & 4 & & 6 & 8 & 10 \text { MILES } \\ 0 & 2 & 4 & 6 & 8 & 10 \text { KILOMETERS }\end{array}$

FIGURE 3A.--Generalized water table of the sand-plain aquifer in Douglas County, Minnesota. 


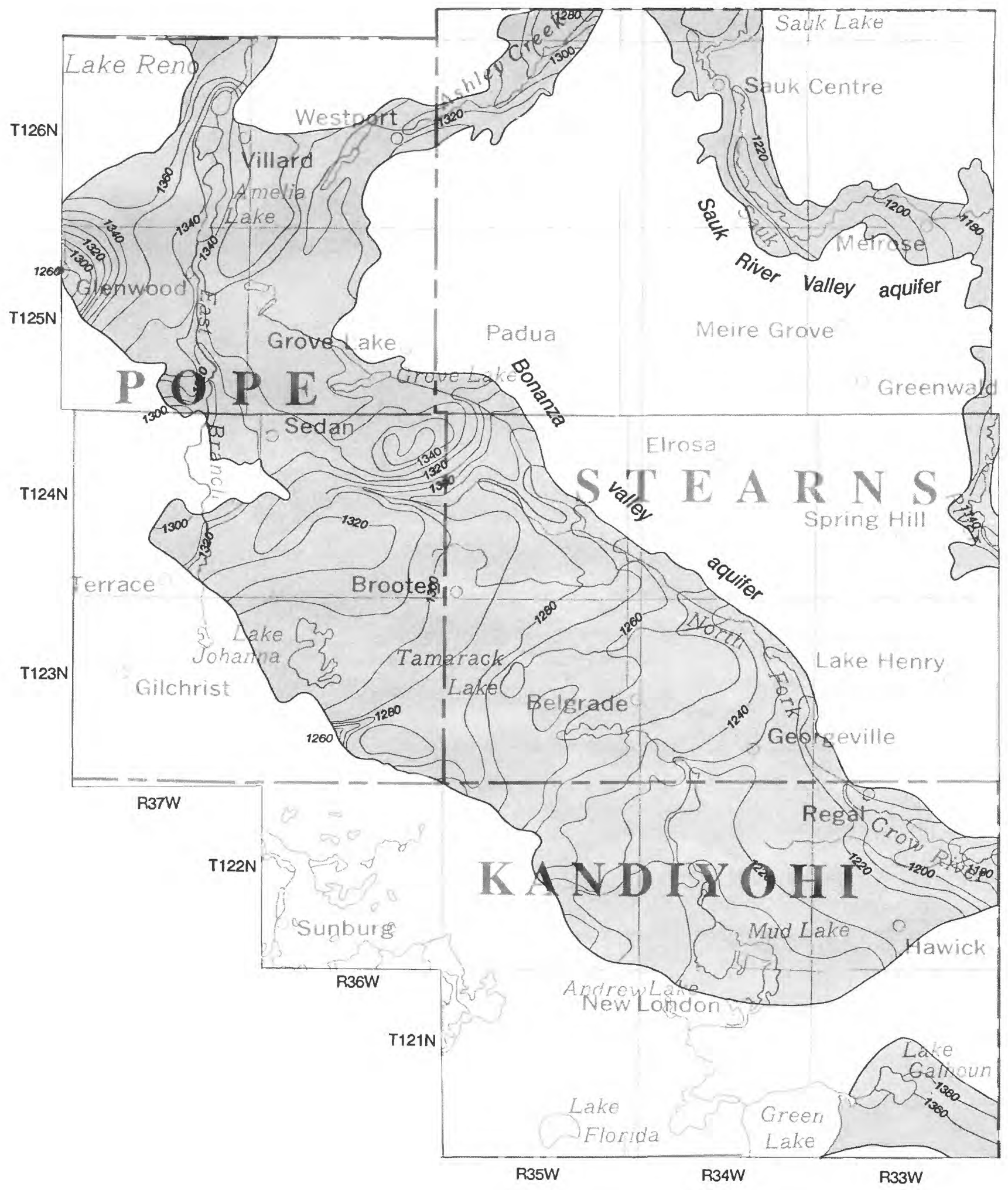

FIGURE 3B.--Generalized water table of the sand-plain aquifers in Pope, Stearns, and Kandiyohi Counties, Minnesota 


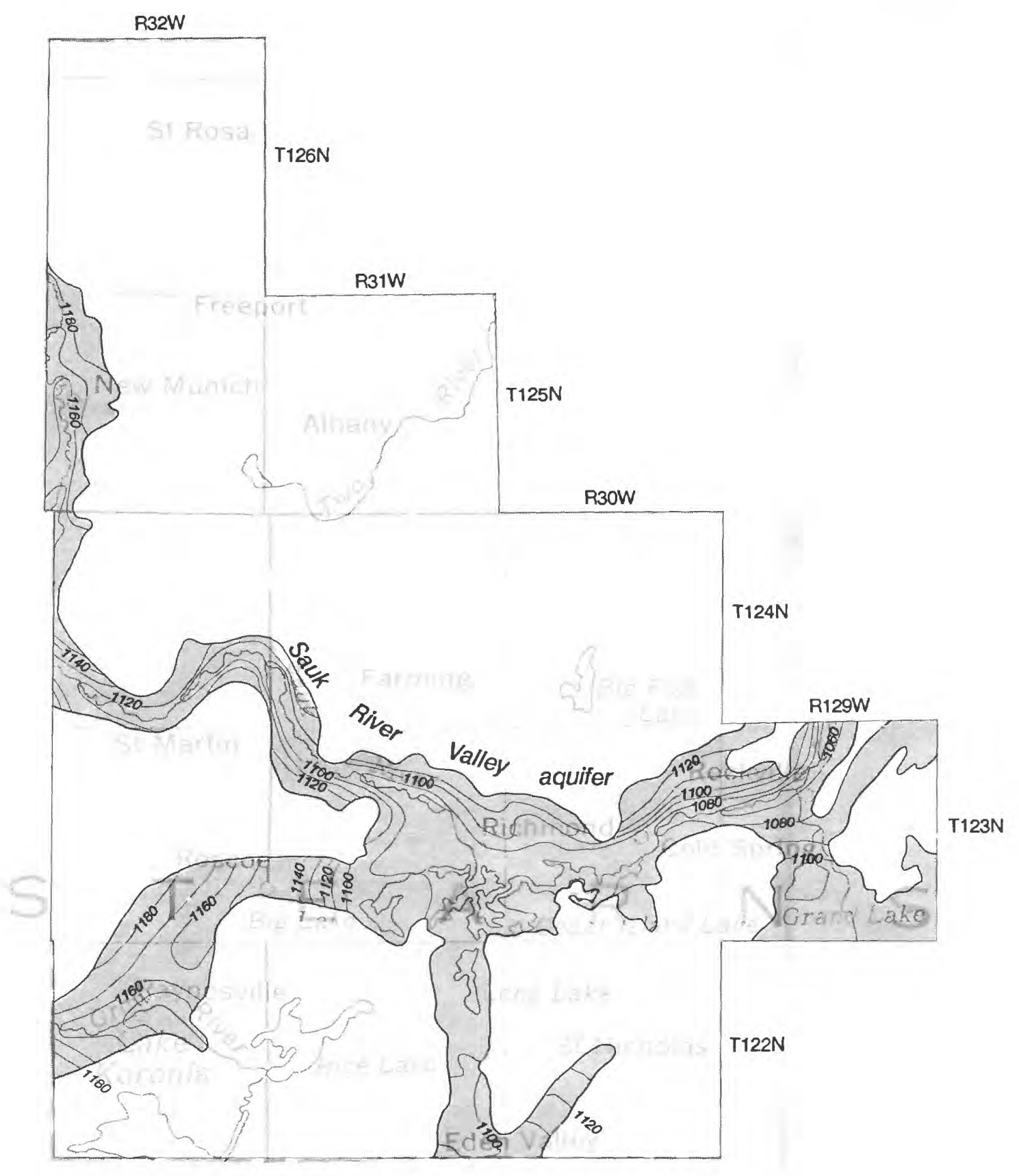

Figure 3C.--Generalized water table of the sand-plain aquifer in Stearns County, Minnesota. 
The average annual fluctuation of the water table in wells screened in the surficial sand-plain aquifers is about 2 feet. The total range in waterlevel fluctuations generally was from 4 to 6 feet during the period from about 1973 to 1984. A hydrograph for a typical observation well (129N36W18CBB01 in Douglas County) is shown in figure 4. The observation well is more than 1,000 feet from any pumping well.

\section{Methods of Investigation}

The effect of agriculture on the quality of water in surficial sand-plain aquifers was evaluated by designing a network of wells to collect ground-water samples from three land-use settings and to determine vertical and areal differences in ground-water quality. From August 1982, through May 1984, 245 water-quality samples were collected from 56 wells. Of the 56 wells, 23 were 2 -inch diameter steel pipe with sand points that were installed for this project, 4 wells were 1-1/4-inch diameter steel pipe with sand points that were installed previously as water-level observation wells, and 29 were private domestic-supply or irrigation wells.

The 56 wells are located directly down the ground-water gradient from one of the three land-use settings to avoid the influence of other land-use activities. Five wells were located downgradient from uncultivated and relatively uninhabited or "natural" areas with minimal effect of agriculture or urbanization, 22 wells were downgradient from nonirrigated cultivated areas, and 29 were downgradient from irrigated cultivated areas. Vertical concentration differences as a possible indication of vertical mixing of chemical constituents were determined by installing and sampling paired wells at each of 11 sites. One well is screened near the water table and the other is 10 or more feet deeper. Areal differences in water quality were determined by distributing the wells to be sampled throughout the different sand-plain aquifers of Douglas, Kandiyohi, Pope, and western Stearns Counties.

Samples were collected from 43 wells to represent a baseline or a reference condition of water quality in fall after the growing season and before fertilizer and pesticide were applied to fields the following year. Baseline samples were analyzed for dissolved concentrations of major inorganic constituents (calcium, magnesium, sodium, potassium, chloride, sulfate, alkalinity, and silica), nutrients (nitrite plus nitrate nitrogen, ammonia, organic nitrogen, and orthophosphate), organic carbon, iron, manganese, fluoride, and boron. Field measurements were made to determine specific conductance, $\mathrm{pH}$, and water temperature. The depth to water was measured during each field visit in all wells with access to the inside of the casing. After baseline samples were analyzed, 13 additional we11s were selected and sampled several times to expand information on water quality in selected areas. 




FIGURE 4.--Hydrograph of water leveis shoving onnual and long-term fluctuations in well 129N36W18CBB01, Douglas County, Minnesota. 
Seasonal variations in water quality in the surficial sand-plain aquifers were observed by sampling 20 wells at 10 sites 5 times in addition to the baseline sampling (February, May, July, and November 1983, and May 1984). Seasonal samples were analyzed for dissolved constituents that may most clearly indicate the effect of agricultural practices on ground-water quality. These dissolved constituents include nutrients (nitrite plus nitrate nitrogen, ammonia, organic nitrogen, and orthophosphate phosphorus), chloride, sulfate, iron, and manganese. Results of a previous study (Myette, 1984) indicated that concentrations of these constituents fluctuate seasonally more than other constituents and appear to be related to agricultural practices. Field measurements of specific conductance, $\mathrm{pH}$, temperature, and depth to water also were made. The range and fluctuation of nitrate concentrations and the importance of nitrate in drinking-water (Minnesota Pollution Control Agency, 1978 , p. 12) indicated the need for seasonal sampling at more then 10 sites. Therefore, 23 baseline wells and 13 other selected wells were sampled one to four times and the samples were analyzed for $\mathrm{pH}$, specific conductance, and dissolved nitrite plus nitrate nitrogen to expand the data base for these constituents.

Long-term changes in water quality were assessed by including 12 wells in the baseline sampling that had been sampled during previous studies in 196578. Results of the previous and recent water-quality analyses were compared, as much as possible, for the same season of the year.

Water samples collected from eight wells during summer 1983 (May-August) were analyzed for triazine herbicides and, at the four wells where herbicides were found in the water, samples were collected again in December 1983 and analyzed. Samples from three sites were analyzed for the insecticide aldicarb.

Water quality analyses were performed at the U.S. Geological Survey's National Water Quality Laboratory in Atlanta, Georgia. Samples were collected, filtered, and preserved; field tests were conducted; and laboratory analyses were performed using the methods of Skougstad and others (1979) for inorganic constituents and nutrients. The methods of Wershaw and others (1983) were used for organic constituents. Aldicarb analyses were done by the Wisconsin State Laboratory of Hygiene in Madison, Wisconsin, and analyzed using a gas chromatograph with a flame photometric detector following an unpublished method developed and described by Union Carbide Corp. ${ }^{1}$, the manufacturer of the pesticide (David Degenhardt, Wisconsin State Laboratory of Hygiene, oral commun., 1985).

Statistical tests were performed to determine the relation of concentrations of various chemical constituents to different areas of the sand-plain aquifers, well depth, and land-use settings. Parametric and nonparametric versions of analysis of variance coupled with Duncan's Multiple Range and Tukey's Studentized Range Tests were used to determine the significance of the relations. An alpha value of 0.05 was used to indicate

\footnotetext{
Ise of firm, brand, or trade names in this report is for identification purposes only and does not constitute endorsement by the U.S. Geological Survey.
} 
that a relation was statistically significant such that there is a 95 percent probability that the relation is not the result of chance sampling. Mean values for $\mathrm{pH}$ were determined by converting mean hydrogen-ion concentrations to $\mathrm{pH}$.

In the analyses run for this study, nitrates were determined as dissolved nitrite plus nitrate nitrogen. In the Anoka Sand Plain, with a similar environment, 81 samples were analyzed for concentrations of dissolved nitrite as nitrogen. Results of these anlayses showed that nitrite concentrations generally ranged from less than 0.01 to $0.05 \mathrm{mg} / \mathrm{L}$; concentrations from 0.2 to $0.9 \mathrm{mg} / \mathrm{L}$ were found in only two samples. Nitrate concentrations in water from sand-plain aquifers generally are greater than $3 \mathrm{mg} / \mathrm{L}$. Because nitrite is present only as a fractional part of a milligram per liter in most natural waters and is an insignificant part of the total concentration of nitrite plus nitrate nitrogen, this report refers to the concentration of dissolved nitrite plus nitrate nitrogen as nitrate.

\section{We11-Numbering Systems}

Wells used in this study are identified in two ways. The first system consists of a 15-digit station-identification number. The first 13 digits are the latitude ( 6 digits) and longitude ( 7 digits) coordinates of the well to the nearest second. The last two digits are sequential numbers used to differentiate between closely spaced wells that have nearly the same latitude and longitude. This system is the primary storage and retrieval key for well data in computer systems of the U.S. Environmental Protection Agency (USEPA) and the U.S. Geological Survey.

Wells also are identified by a local well-numbering system consisting of the township, range, and section numbers followed by uppercase letters, A, B, $C$, or $D$ that located the well within the section (fig. 5). The first letter following the section number denotes the quarter section, or 160-acre tract, the second denotes the quarter-quarter section, or 40-acre tract, and the third denotes the quarter-quarter-quarter section, or 10-acre tract. A sequential number at the end of the local well number distinguishes wells within the same 10-acre tract. Figure 5 shows well 123N35W14ADC01 to be in the SW $1 / 4 \mathrm{SE} 1 / 4 \mathrm{NE} 1 / 4$, section 14, township 123 north, range 35 west, and the sequential number shows it to be the first well in the 10-acre tract. This identification system, which is familiar to most property owners, is the principal system used in this report.

\section{Acknowledgments}

The author would like to thank all the property owners for their cooperation and use of their wells for water sampling, and the Soil and Water Conservation Districts of Douglas, Kandiyohi, Pope, and Stearns Counties for providing the local Steering Committee that aided progress of this study. Appreciation is extended to Harold Anderson, Minnesota Soil and Water Conservation Board Representative for the West Central Administrative Region, for leadership on the Steering Committee; to Jerry Wright, Area Extension 




FIGURE 5.--Example of well-numbering system. 
Irrigation Engineer with the Agricultural Extension Service, University of Minnesota, for information on local irrigation; Bud Reece with WESMIN Resource Conservation and Development Project Office, for local budget planning; and Dr. Joseph Rossillon, President of the Freshwater Foundation, Navarre, Minnesota, for information and support related to pesticide analyses in this project.

\section{GROUND-WATER QUALITY}

The chemical quality of water in the surficial sand-plain aquifers is influenced by areal differences in the natural environment, depth below the water table, land use, season, and many other factors. The kind and amount of dissolved constituents depend on the composition and grain size of the geologic materials through which the water moves and on the length of time that water and materials are in contact. The amount and timing of precipitation is an important factor. Ground-water quality also is influenced by the activities of man. Chemical and petroleum spills, highway salts, use of fertilizers and pesticides, and discharge of wastes to the ground can change the quality of ground water in the sand-plain areas because of relatively high infiltration rates.

The suitability of the water varies according to use and, in the sandplain areas, water from surficial aquifers is used mainly for drinking and irrigation. In Minnesota, the most restrictive standards are applied to water used for drinking (Minnesota Pollution Control Agency, 1978, p. 12) and food processing (table 1). The quality of water from wells in the project area generally meets those standards. Exceptions are found in water from shallow wells completed near the water table, which are particularly susceptable to water-quality degradation from chemicals percolating from land surface. Some chemicals of special concern in the sand plains contain sulfate, chloride, nitrate, and pesticides. Table 1 shows that although all samples meet the sulfate, chloride, and fluoride standards, more than 50 percent of the 56 wells sampled had a concentration of nitrate greater than the state recommended limit for drinking water. Elevated concentrations of nitrate may result from excessive applicaitons of fertilizer, barnyard or feedlot seepage, sewage and septic systems, or infiltracion of nitrates from decomposition of organic material in the soil horizon of cultivated fields. Contamination by pesticides also is of special concern because relatively little is known of the occurrence and persistence of pesticides in ground water in Minnesota. 
Table 1.--Minnesota standards for drinking water, and number of samples in which the recommended limit was exceeded

[Concentrations in milligrams per liter]

\begin{tabular}{|c|c|c|c|c|c|}
\hline Constituent & $\begin{array}{r}\text { Minnesota } \\
\text { standard }\end{array}$ & $\begin{array}{c}\text { Number of } \\
\text { samples }\end{array}$ & $\frac{\text { Number th }}{\text { Samples }}$ & We11s & $\frac{\text { standard }}{\text { Sites }}$ \\
\hline $\begin{array}{c}\text { Total dissolved } \\
\text { solids }\end{array}$ & 500 & 43 & 1 & 1 & 1 \\
\hline Sulfate $\left(\mathrm{SO}_{4}\right)$ & 250 & 135 & 0 & 0 & 0 \\
\hline Chloride (C1) & 250 & 135 & 0 & 0 & 0 \\
\hline Fluoride (F) & 1.5 & 43 & 0 & 0 & 0 \\
\hline Nitrate (N) & 10 & 245 & 94 & 29 & 24 \\
\hline Iron ( $\mathrm{Fe})$ & .30 & 115 & 37 & 15 & 11 \\
\hline Manganese (Mn) & .05 & 115 & 55 & 22 & 18 \\
\hline
\end{tabular}




\section{Regional Water Quality}

The quality of water from 43 wells in the surficial sand-plain aquifers is summarized in table 2, which lists results of analyses for major ions, nutrients, iron, and manganese. Water samples were collected in August 1982 in Douglas, Pope, and Stearns Counties and in June 1983 in Kandiyohi County. These data can be used as a baseline or a point of reference in time for future assessments of long-term trends in water quality. Table 2 lists the mean, standard deviation, median, minimum, and maximum value for 43 baseline samples analyzed for various constituents.

Water in the study area is a calcium bicarbonate type and is suitable for most uses. Ranges in concentration for some constituents were large--3 to 160 $\mathrm{mg} / \mathrm{L}$ sulfate, 2.1 to $53 \mathrm{mg} / \mathrm{L}$ chloride, < (less than) 0.1 to $52 \mathrm{mg} / \mathrm{L}$ nitrate, $<0.01$ to $0.32 \mathrm{mg} / \mathrm{L}$ ammonia, $<0.003$ to $5.3 \mathrm{mg} / \mathrm{L}$ iron, and $<0.001$ to $1.5 \mathrm{mg} / \mathrm{L}$ manganese (table 2).

Locally elevated sulfate concentrations might be the result of local application of ammonium sulfate fertilizer, the discharge of sewage, and/or runoff from feedlots. The baseline sample that had the highest sulfate concentration, $160 \mathrm{mg} / \mathrm{L}$, was collected less than a mile downgradient from a cattle feedlot. Elevated concentrations of chloride may be related to road salting, but elevated chloride concentrations, like elevated sulfate concentrations, commonly are related to the discharge of sewage and/or runoff from cattle yards and feedlots. The same sample collected downgradient from a cattle feedlot, which had a sulfate concentration of $160 \mathrm{mg} / \mathrm{L}$, also had a chloride concentration of $53 \mathrm{mg} / \mathrm{L}$.

The range in concentration of nitrate locally is influenced by sewage discharge and runoff from cattle yards, but use of fertilizers appears to have the greatest influence on nitrate concentrations in ground water. The sample with elevated concentrations of sulfate and chloride, mentioned above, had a nitrate concentration of only $0.18 \mathrm{mg} / \mathrm{L}$. Nitrates may have been reduced in the feedlot runoff by plants in a swampy area between the feedlot and the sampled we11. Many samples with elevated nitrate concentrations were collected downgradient from irrigated and nonirrigated fields planted in corn and potatoes. Although cattle yards were expected to be a source of elevated concentrations of nitrate in the ground water, this was not observed at the site mentioned above.

The highest concentration of ammonium nitrogen determined $(0.32 \mathrm{mg} / \mathrm{L})$ in baseline samples was from a well screened 15 feet below the water table in the Carlos Outwash area, Douglas County.

Ranges in concentrations of iron and manganese in the 43 baseline samples were large. Iron exceeded the Minnesota drinking-water standard in 21 percent of the samples, and manganese exceeded the standard in 46 percent of the samples. The source of elevated iron and manganese seems to be natural and not caused by pollution. 
Table 2.--Statistical summary of 43 baseline chemical analyses of water from surficial sand-plain aquifers in Douglas, Kandiyohi,

Pope, and Stearns Counties, west-central Minnesota, in fall 1982 and spring 1983

[Water level and well depth in feet below land surface; other values in milligrams per liter, except as noted]

\begin{tabular}{|c|c|c|c|c|}
\hline $\begin{array}{l}\text { Constituent } \\
\text { or property }\end{array}$ & Mean & Median & Minimum & Maximum \\
\hline Water level (28 wells) & 9.95 & 8.66 & 2.30 & 32.37 \\
\hline Depth of well ( 43 wells) & 24 & 21.0 & 6.5 & 73 \\
\hline $\begin{array}{l}\text { Specific conductance } \\
\text { (microsiemens/centimeter } \\
\text { at } 25{ }^{\circ} \text { Celsius) }\end{array}$ & 627 & 620 & 350 & 1,120 \\
\hline $\mathrm{pH}$ (standard units) & 7.5 & 7.7 & 6.5 & 8.9 \\
\hline Temperature, water ( ${ }^{\circ} \mathrm{Celsius)}$ & 10 & 9.5 & 8.0 & 17 \\
\hline Hardness, (as $\mathrm{CaCO}_{3}$ ) & 307 & 300 & 150 & 600 \\
\hline Calcium, dissolved (as $\mathrm{Ca}$ ) & 81 & 78 & 40 & 160 \\
\hline Magnesium, dissolved (as Mg) & 28 & 25 & 13 & 49 \\
\hline Sodium, dissolved (as $\mathrm{Na}$ ) & 4.6 & 3.3 & 1.0 & 32 \\
\hline Potassium, dissolved (as $\mathrm{K}$ ) & 2.7 & 1.7 & .1 & 17 \\
\hline Alkalinity, total (as $\mathrm{CaCO}_{3}$ ) & 240 & 230 & 160 & 340 \\
\hline Sulfate, dissolved (as $\mathrm{SO}_{4}$ ) & 28 & 22 & 3.0 & 160 \\
\hline Chloride, dissolved (as $\mathrm{Cl}$ ) & 15 & 12 & 2.1 & 53 \\
\hline Fluoride, dissolved (as F) & .2 & .2 & $<.1$ & .3 \\
\hline Silica, dissolved (as $\mathrm{SiO}_{2}$ ) & 21 & 21 & 8.1 & 31 \\
\hline $\begin{array}{l}\text { Dissolved solids, calculated, } \\
\text { sum of constituents }\end{array}$ & 324 & 320 & 190 & 650 \\
\hline $\begin{array}{l}\text { Nitrite + nitrate, } \\
\text { dissolved (as } N \text { ) }\end{array}$ & 9.9 & 7.9 & $<.1$ & 52 \\
\hline $\begin{array}{r}\text { Nitrogen, ammonia, } \\
\text { dissolved (as } N \text { ) }\end{array}$ & .08 & .05 & $<.01$ & .3 \\
\hline $\begin{array}{l}\text { Nitrogen, dissolved } \\
\text { organic (as } N \text { ) }\end{array}$ & .87 & .29 & $<.01$ & 11 \\
\hline $\begin{array}{l}\text { Phosphorus, dissolved } \\
\text { orthophosphate (as P) }\end{array}$ & .02 & .01 & $<.01$ & .05 \\
\hline Boron, dissolved (as B) & .06 & .03 & .01 & .3 \\
\hline Iron, dissolved (as $F_{\theta}$ ) & .48 & .023 & $<.003$ & 5.3 \\
\hline Manganese, dissolved (as Mn) & .18 & .024 & $<.001$ & 1.5 \\
\hline Carbon, organic dissolved (as $C$ ) & 2.1 & 1.8 & .8 & 7.4 \\
\hline
\end{tabular}


To assess the areal variation in the quality of water from the surficial sand-plain aquifers underlying the $600 \mathrm{mi}^{2}$ area, data were tabulated by county for Douglas, Kandiyohi, Pope, and Stearns Counties. Only minor differences were observed in mean concentrations of major ions throughout the counties. Some differences in nitrate were noted, but the concentration differences seemed to be more clearly related to differences between land use and size of the three sand-plain areas. Mean dissolved solids concentrations ranged from $297 \mathrm{mg} / \mathrm{L}$ in Pope County to $369 \mathrm{mg} / \mathrm{L}$ in Stearns County. Mean specific conductance ranged from $569 \mu \mathrm{S} / \mathrm{cm}$ (microsiemens per centimeter at $25^{\circ} \mathrm{Celsius}$ ) in Pope County to $723 \mu \mathrm{S} / \mathrm{cm}$ in Stearns County. These differences do not appear to be substantial. The mean concentration of boron in Pope County, $0.09 \mathrm{mg} / \mathrm{L}$, was about twice as high as in the other counties, which reflects a general southwesterly increase in boron towards western Minnesota.

Only minor differences were observed in mean concentrations of most major ions (table 3 ) between the three sand-plain areas: Bonanza Valley, Viking Basin, and Sauk River valley (fig. 2). However, mean and median sulfate values were almost twice as large in the Sauk River valley as in the other two areas. Mean values for iron and manganese also were about twice as large in the Sauk River valley as in the other two areas. The mean value for nitrate was about the same in the three areas, but the median value for nitrate nitrogen was only $5.8 \mathrm{mg} / \mathrm{L}$ in the Sauk River valley, compared to $6.3 \mathrm{mg} / \mathrm{L}$ in the Bonanza Valley, and $10 \mathrm{mg} / \mathrm{L}$ in the Viking Basin. The similarity of both mean and median concentrations for most constituents suggests normal statistical distribution of concentrations. For nitrate, ammonia, dissolved organic nitrogen, iron, and manganese, the mean is substantially greater than the median concentration because of a few very high values. 
Table 3.--Mean and median concentrations for selected constituents in the three sand-plain areas

[Concentrations in milligrams per liter unless otherwise noted]

\begin{tabular}{|c|c|c|c|c|c|c|c|c|c|}
\hline \multirow[b]{2}{*}{$\begin{array}{l}\text { Constituent } \\
\text { or property }\end{array}$} & \multicolumn{3}{|c|}{ Bonanza Valley } & \multicolumn{3}{|c|}{ Viking Basin } & \multicolumn{3}{|c|}{ Sauk River valley } \\
\hline & $\begin{array}{l}\text { Number } \\
\text { of } \\
\text { samples }\end{array}$ & Mean & Median & $\begin{array}{l}\text { Number } \\
\text { of } \\
\text { samples }\end{array}$ & Mean & Median & $\begin{array}{l}\text { Number } \\
\text { of } \\
\text { samples }\end{array}$ & Mean & Median \\
\hline \multicolumn{10}{|l|}{$\begin{array}{l}\text { Specific conductance } \\
\text { (microsiemens/centimeter }\end{array}$} \\
\hline $\begin{array}{l}\left.\text { at } 25{ }^{\circ} \mathrm{Celsius}\right) \ldots \ldots \\
\text { Hardness, as }\end{array}$ & 140 & 618 & 600 & 56 & 633 & 575 & 57 & 727 & 700 \\
\hline $\begin{array}{l}\mathrm{CaCO}_{3},(\mathrm{Ca}, \mathrm{Mg}) \ldots \ldots \ldots \\
\text { Calcium, dissolved }\end{array}$ & 25 & 300 & 300 & 9 & 270 & 250 & 9 & 360 & 320 \\
\hline $\begin{array}{l}\text { (as } C a) \ldots \ldots \ldots \ldots \ldots \\
\text { Magnesium, dissolved }\end{array}$ & 25 & 79 & 78 & 9 & 73 & 71 & 9 & 93 & 83 \\
\hline $\begin{array}{l}\left.\text { (as } M_{g}\right) \ldots \ldots \ldots \ldots \ldots \\
\text { Sodium, dissolved }\end{array}$ & 25 & 26 & 25 & 9 & 21 & 19 & 9 & 30 & 27 \\
\hline $\begin{array}{l}\text { (as } \mathrm{Na} \text {................... } \\
\text { Potassium, dissolved }\end{array}$ & 25 & 4.8 & 3.2 & 9 & 2.6 & 2.0 & 9 & 6.0 & 4.3 \\
\hline $\begin{array}{l}(\text { as } \mathrm{K}) \ldots \ldots \ldots \ldots \ldots \ldots \\
\text { Alkalinity, total }\end{array}$ & 25 & 3 & 2 & 9 & 1 & 1 & 9 & 3 & 2 \\
\hline $\begin{array}{l}\left.\text { (as } \mathrm{CaCO}_{3}\right) \ldots \ldots \ldots \ldots \ldots \\
\text { Sulfate, dissolved }\end{array}$ & 25 & 240 & 230 & 9 & 220 & 200 & 9 & 270 & 290 \\
\hline $\begin{array}{l}\left.\text { (as } \mathrm{SO}_{4}\right) \ldots \ldots \ldots \ldots \ldots \\
\text { Chloride, dissolved }\end{array}$ & 76 & 21 & 17 & 30 & 21 & 19 & 29 & 40 & 38 \\
\hline $\begin{array}{l}\text { (as } C 1) \ldots \ldots \ldots \ldots \ldots \ldots \\
\text { Fluoride, dissolved }\end{array}$ & 76 & 18 & 16 & 30 & 9.3 & 9.0 & 29 & 22 & 15 \\
\hline $\begin{array}{l}\text { (as F) } \ldots \ldots \ldots \ldots \ldots \ldots \\
\text { Silica, dissolved }\end{array}$ & 25 & .1 & .1 & 9 & .2 & .2 & 9 & .2 & .2 \\
\hline $\begin{array}{l}\left.\text { (as } \mathrm{SiO}_{2}\right) \ldots \ldots \ldots \ldots \ldots \\
\text { Dissolved solids, } \\
\text { calculated, sum of }\end{array}$ & 25 & 22 & 23 & 9 & 22 & 22 & 9 & 18 & 20 \\
\hline 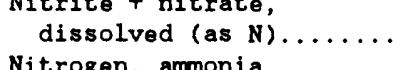 & 140 & 10 & 6.3 & 54 & 13 & 10 & 51 & 12 & 5.8 \\
\hline $\begin{array}{l}\text { Nitrogen, ammonia, } \\
\text { dissolved (as } N) \ldots \ldots \ldots \\
\text { Nitrogen, dissolved }\end{array}$ & 77 & .16 & .06 & 30 & .15 & .08 & 29 & .13 & .10 \\
\hline $\begin{array}{l}\text { organic (as } N \text { ) .......... } \\
\text { Phosphorus, dissolved } \\
\text { orthophosphate }\end{array}$ & 66 & .59 & .21 & 25 & .30 & .18 & 25 & .27 & .17 \\
\hline (as $\mathrm{P}) \ldots \ldots \ldots \ldots \ldots$ & 65 & .01 & .01 & 25 & .03 & .02 & 25 & .02 & .01 \\
\hline Boron, dissolved (as B)... & 25 & .08 & .03 & 9 & .02 & .02 & 9 & .03 & .03 \\
\hline $\begin{array}{l}\text { Iron, dissolved (as } F \theta \text { )... } \\
\text { Manganese, dissolved }\end{array}$ & 65 & .66 & .06 & 25 & .99 & .12 & 25 & 1.6 & .53 \\
\hline 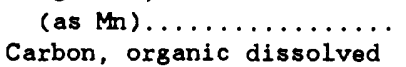 & 65 & .14 & .02 & 25 & .11 & .03 & 25 & .27 & .11 \\
\hline (as C) $\ldots \ldots \ldots \ldots \ldots \ldots$ & 38 & 1.9 & 1.6 & 15 & 2.0 & 1.9 & 13 & 2.1 & 1.9 \\
\hline
\end{tabular}




\section{Vertical Distribution of Water-Quality Constituents}

A tabulation of water-quality data by depth below the water table (table 4) shows substantial vertical differences in mean concentration of chloride, nitrate, ammonia, iron, and manganese. Data in table 4 were collected from fall 1982, through spring 1984. Mean and maximum values of chloride and nitrate decreased with depth, which suggests that the source of chloride and nitrate is at the surface. These constituents, in agricultural areas, can be related to fertilizer use and, locally, to seepage from cattle yards, feedlots, and septic systems. Ammonia nitrogen increases from 10 to 20 feet below the water table and then decreases at more than 20 feet below. The increase may be related to denitrification and/or other chemical reactions and changes in constituents taking place within the aquifer. Mean iron and manganese concentrations are highest from 10 to 20 feet below the water table. This may be related to solution of iron and manganese present in the aquifer materials.

Large vertical differences in nitrate concentrations were found at 11 paired-well sites where one well is screened near the water table and a second well 10 or more feet below. Vertical differences also were observed in specific conductance and concentrations of iron, chloride, and sulfate. At eight of the paired-well sites, nitrate concentrations were higher near the water table than deeper in the aquifer. At the three other paired-well sites, nitrate concentrations increased with depth below the water table. Mean nitrate concentrations in the water-table and deeper wells for these two groups of well sites are shown in the following table. Ranges in nitrate concentrations at each of the 11 paired-well sites are shown in table 5 .

Hean nitrite plus nitrate nitrogen concentration in water-table and deeper wells in Douglas, Kandiyohi, Pope, and Stearns Counties

\begin{tabular}{lcc}
\hline \multicolumn{1}{c}{$\begin{array}{c}\text { Number } \\
\text { of } \\
\text { Wells }\end{array}$} & $\begin{array}{c}\text { Mean nitrite plus } \\
\text { sitrate concentration } \\
\text { (milligrams per liter) }\end{array}$ \\
\hline At eight sites with high & nitrate concentration at water table \\
Water table & 46 & 23 \\
Deeper & 44 & 3.9 \\
& & \\
At three sites with & low nitrate concentration at water table \\
Water table & 16 & 4.8 \\
Deeper & 16 & 14 \\
\hline
\end{tabular}




(4)

\begin{tabular}{|c|c|c|c|c|}
\hline 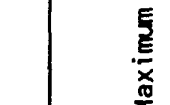 & 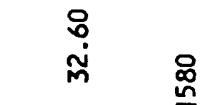 & 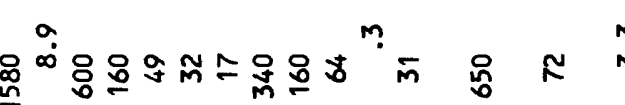 & $\stackrel{m}{m}=$ & 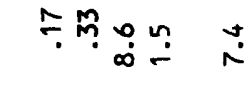 \\
\hline 产 & $\begin{array}{lll}\hat{\infty} \\
\infty\end{array}$ & 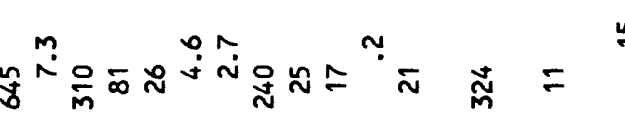 & $\stackrel{n}{?}$ & 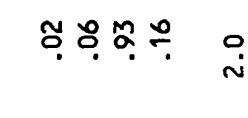 \\
\hline $\mid$ & $\stackrel{\overbrace{}}{\approx}$ & 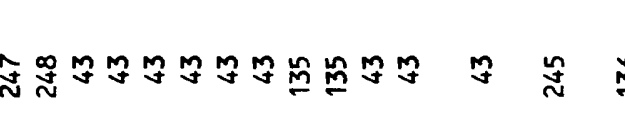 & $\stackrel{2}{\cong}$ & \\
\hline & $\stackrel{9}{\sim}$ & 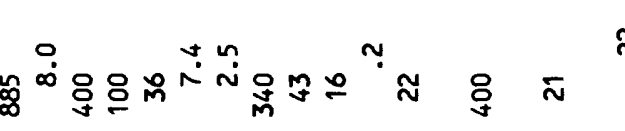 & $\approx$ ษ & 草 \\
\hline 稾 & $\underset{0}{5}$ & $\tilde{b}$ & $\cong \bar{\varphi}$ & 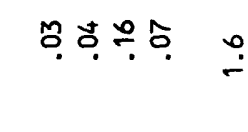 \\
\hline  & \pm & 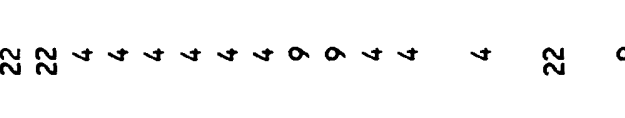 & $a \infty$ & n \\
\hline & 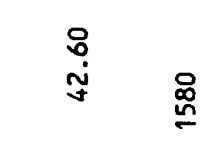 &  & $\stackrel{m}{m} \underset{\infty}{m}$ & $\ddot{m}$ \\
\hline 重 & $\overline{\bar{\alpha}}$ & 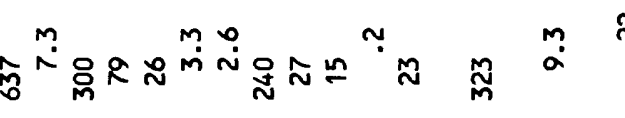 & $\approx$ & 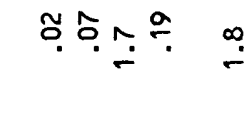 \\
\hline  & $\$ \quad \stackrel{0}{\square}$ & 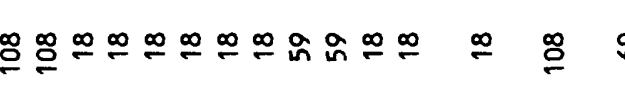 & $8=$ & 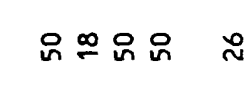 \\
\hline E & $\stackrel{\substack{n \\
\sim}}{\stackrel{0}{=}}$ & 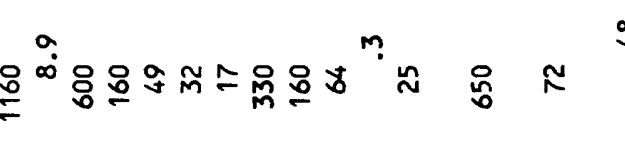 & $\stackrel{\infty}{=}=$ & : \\
\hline ฐ్ & $\stackrel{\circ}{\circ} \tilde{\Xi}$ &  & $\stackrel{9}{9}$ & \\
\hline 寒。 & $\cong \cong$ &  & & \\
\hline 起 & 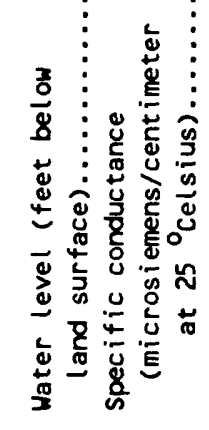 &  & 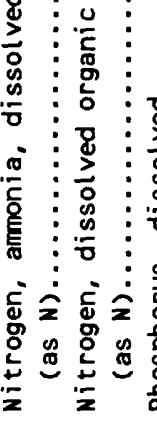 & 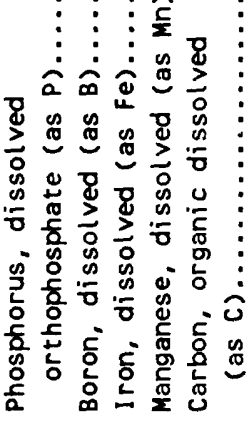 \\
\hline
\end{tabular}


Higher nitrate concentrations at the water table and lower concentrations at depth (table 4) is the most common situation throughout the sand-plain aquifers. All three sites (table 5) where nitrate concentrations were lower at the water table than at depth are near areas where intermittent ponds form during heavy precipitation. Samples collected from two of the ponds had nitrate concentrations less than $1 \mathrm{mg} / \mathrm{L}$. Water in the ponds drains rapidly downward through the permeable sandy soils. The large amount of dilute recharge from the ponds may displace high-nitrate water near the water table to deeper in the aquifer, resulting in lower nitrate concentrations at the water table.

Water from deeper wells (table 5) in the broad sand-plain aquifers in the Viking Basin and Bonanza Valley has higher and more variable nitrate concentrations than water from deeper wells in the narrower Sauk River valley aquifer. These locally higher nitrate concentrations at depth in the broad sand plains but not in the narrow sand plains may be related to differences between regional and local circulation patterns in the ground-water system. Large differences between nitrates in water-table and deeper wells may indicate regional circulation systems (fig. 6a), as illustrated by Freeze and Witherspoon (1967). Regional circulation and little mixing occurs in the narrow Sauk River valley aquifer where the flow path is short and the water table has a smooth continuous gradient from the valley wall to the river.

Table 5.--Range of nitrite plus nitrate nitrogen concentrations in water-table and deeper wells in the study area

[Concentrations in milligrams per liter; <, less than]

\begin{tabular}{|c|c|c|c|c|c|c|c|}
\hline County & Area & $\begin{array}{l}\text { Land-use } \\
\text { setting }\end{array}$ & $\begin{array}{l}\text { Number } \\
\text { of } \\
\text { samples }\end{array}$ & $\begin{array}{c}\text { Nitrate } \\
\text { concentrations } \\
\text { in } \\
\text { water-table } \\
\text { wells }\end{array}$ & $\begin{array}{l}\text { Number } \\
\text { of } \\
\text { samples }\end{array}$ & $\begin{array}{c}\text { Nitrate } \\
\text { concentrations } \\
\text { in } \\
\text { deeper } \\
\text { wells }\end{array}$ & $\begin{array}{c}\text { Well } \\
\text { depth } \\
\text { below } \\
\text { water-table } \\
\text { (feet) }\end{array}$ \\
\hline \multicolumn{8}{|c|}{ WELL SITES WITH ELEVATED NITRATE CONCENTRATION AT WATER TABLE } \\
\hline Stearns & Sauk River valley & $\begin{array}{l}\text { Nonirrigated } \\
\text { cultivated }\end{array}$ & 6 & $14-54$ & 6 & $<0.1-0.8$ & 19 \\
\hline Stearns & Sauk River valley & Irrigated & 6 & $18-72$ & 6 & $<.1-0.27$ & 27 \\
\hline Douglas & Viking Basin & $\begin{array}{l}\text { Nonirrigated } \\
\text { cultivated }\end{array}$ & 6 & $5.0-17$ & 6 & $<.1-0.18$ & 15 \\
\hline Pope & Bonanza Valley & Uncultivated & 5 & $4.8-20$ & 5 & $<.1-0.13$ & 33 \\
\hline Pope & Bonanza Valley & $\begin{array}{l}\text { Nonirrigated } \\
\text { cultivated }\end{array}$ & 6 & $4.3-6.0$ & 6 & $.29-1.1$ & 23 \\
\hline Pope & Bonanza Valley & Irrigated & 5 & $5.6-13$ & 3 & $<.1-0.22$ & 30 \\
\hline Pope & Bonanza Valley & Irrigated & 6 & $11-33$ & 6 & $2.0-14$ & 25 \\
\hline \multirow[t]{2}{*}{ Stearns } & Bonanza Valley & Irrigated & 6 & $17-66$ & 6 & $9.8-32$ & 14 \\
\hline & WE & SITES WITH LOW & N NITRATE & CONCENTRATION AT & WATER TABLE & & \\
\hline Douglas & Viking Basin & Irrigated & 6 & $1.5-12$ & 6 & $15-21$ & 23 \\
\hline Kandiyohi & Bonanza Valley & $\begin{array}{l}\text { Nonirrigated } \\
\text { cultivated }\end{array}$ & 5 & $<.1-0.22$ & 5 & $5.8-9.0$ & 19 \\
\hline Kandiyohi & Bonanza Valley & Irrigated & 5 & $1.8-11$ & 5 & $8.5-21$ & 15 \\
\hline
\end{tabular}




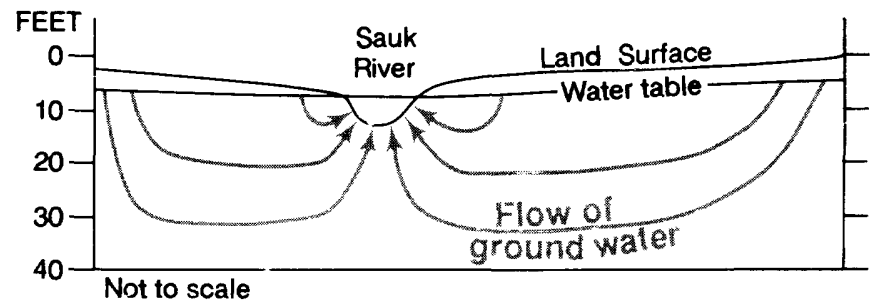

(a) Local relief negligible; regional circulation is smooth laminar flow. Little mixing occurs.



(b) Pronounced local relief; local circulation predominates. Much mixing occurs.

FIGURE 6.--Generalized effect of topographic relief on the flow of ground water.

(a) Diagrammatic section across the Sauk River valley.

(b) Diagrammatic section in the Bonanza Valley. 
In contrast, the higher nitrates in water from deeper wells in broad sand-plain aquifers, such as the Bonanza Valley and Viking Basin may result from a longer flow path, more localized circulation (fig. 6b), and/or greater vertical mixing of ground water bringing some high-nitrate water to greater depth. Local relief on the water table of only a few feet up or down can form local circulation systems resulting in more vertical mixing of the ground water (fig. 6b).

The greater amount of mixing of ground water in the Bonanza Valley and Viking Basin aquifers also may be related to local water-level fluctuations in cones of depression around high-capacity wells in irrigated areas. Water from the water table containing elevated nitrate concentrations may flow down the steep hydraulic gradient of the cone of depression surrounding a highcapacity pumping well, thereby increasing the amount of nitrate at greater depth.

Higher-nitrate concentrations at the water table and lower concentrations at greater depth in the narrow Sauk River valley aquifer (table 5, and fig. 7) are associated with cultivated sites, either with or without irrigation. Recharge from precipitation in these areas travels a short distance laterally and discharges to the river with relatively little mixing.

In some areas, nitrate is present at shallow depth and diminishes in concentration as the water moves deeper into the flow system. Edmunds (1973) and Gillham and Cherry (1978) attributed this trend in nitrate concentrations to the biochemical process of denitrification, which requires denitrifying bacteria, organic material, other nutrients necessary for growth of bacteria, and a moderate redox (oxidation-reduction) potential. In their discussion of redox processes, Freeze and Cherry (1979, p. 114-118) list reactions in which nitrate is converted to the gases nitrogen or nitrous oxide or to the ions nitrite or ammonium. Their description of the denitrification process indicates that organic matter combines with nitrate to form nitrogen gas, bicarbonate, hydrogen ions, and water. If the environmental conditions are correct, this process could account for at least some of the vertical differences in nitrate concentration in the surficial sand-plain aquifers.

Denitrification may be occurring near the paired-wells in the Carlos outwash area, Douglas County, where nitrate concentrations in the water-table well were greater ( 5.0 to $17.0 \mathrm{mg} / \mathrm{L})$ than in the adjacent well screened 15 feet below the water table $(<0.1$ to $0.18 \mathrm{mg} / \mathrm{L})$, and the ammonium concentration was greater in the deeper well $(0.32$ to $0.52 \mathrm{mg} / \mathrm{L})$ than in the water-table we $11(0.02$ to $0.27 \mathrm{mg} / \mathrm{L})$. Bicarbonate concentrations, indicated by alkalinity, also were greater in the deeper well, as would be expected if denitrification were occurring at depth. Comparative values of $\mathrm{pH}$ in the paired wells do not indicate any consistent difference with depth. The concentration of dissolved organic carbon was 2 to $3 \mathrm{mg} / \mathrm{L}$ in both the shallow and the deeper wells. 


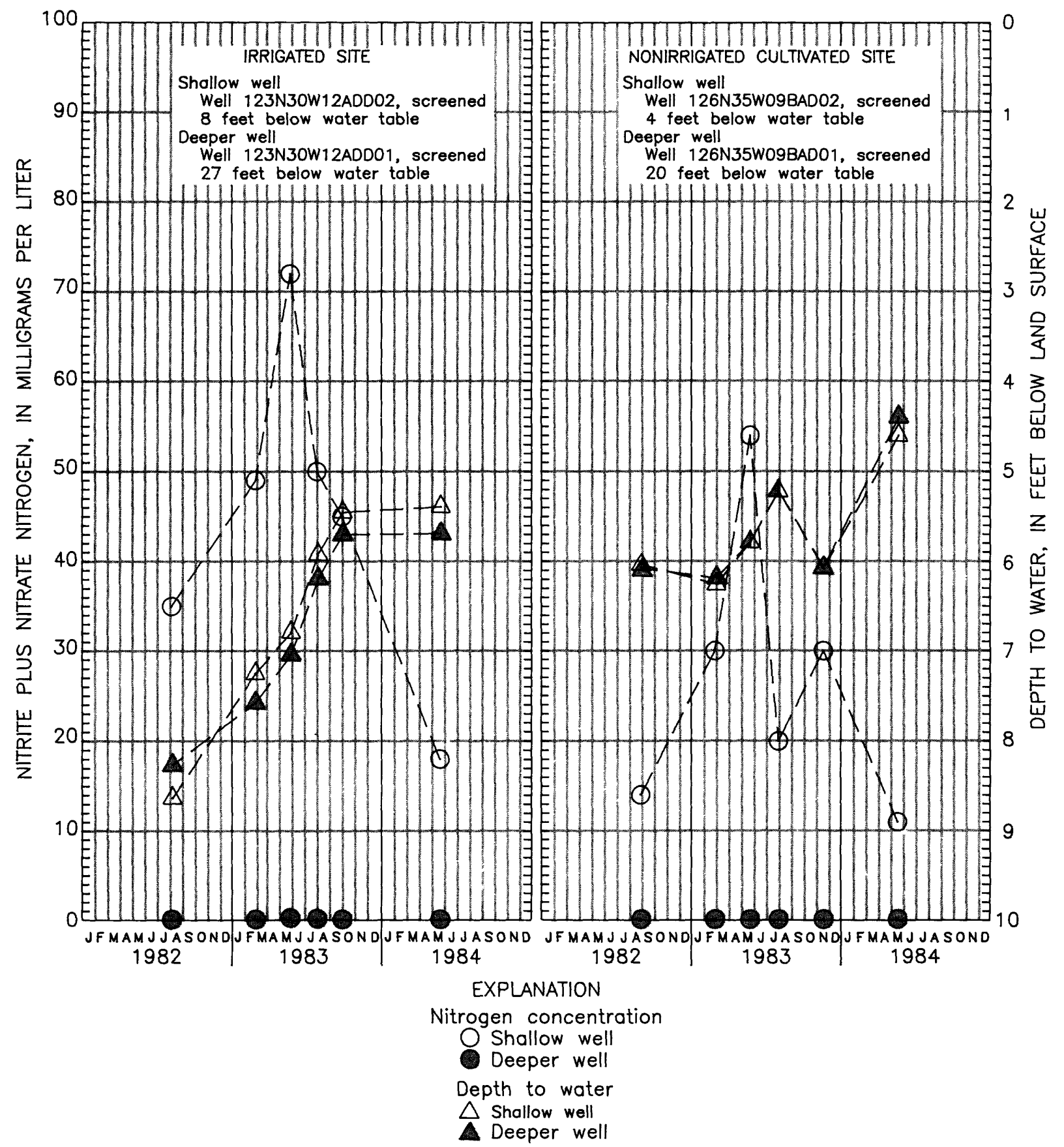

FIGURE 7.--Seasonal fluctuations in water levels and concentrations of nitrite plus nitrate nitrogen at two well sites in the Sauk River valley, Stearns County, Minnesota. 


\section{Seasonal Changes In Water Quality}

Seasonal fluctuations were observed in concentrations of nitrate, sulfate, chloride, iron, and manganese. Spearman correlation coefficients indicate that nitrate nitrogen concentrations directly correlate with specific conductance and chloride concentrations. Where nitrate is elevated, so is chloride, indicating that both may come from the same source--nitrogen from nitrate and ammonium and chloride from potassium chloride in fertilizer. There is a negative correlation of nitrate concentrations with iron and manganese concentrations. Where concentrations of nitrate are high, iron and manganese are low, suggesting different sources or oxidizing conditions in the aquifer. Some seasonal changes also were observed in ammonium and organic nitrogen, but not in phosphorous.

Seasonal fluctuations in water levels and in concentrations of selected constituents are shown in table 6 . Water-level fluctuations in wells sampled during this study correlate with the general trend seen in long-term waterlevel-observation wells in the area. The rising water level from August 1982 to May 1984 (fig. 7 and table 6) indicates increased recharge to the aquifer. Comparison of seasonal constituent values with seasonal water levels may provide insight into movement of chemical constituents from the land surface to the water table.

Mean nitrate concentrations rose from $13.0 \mathrm{mg} / \mathrm{L}$ in fall 1982 to $14 \mathrm{mg} / \mathrm{L}$ in winter 1983 as recharge, indicated by rising water level, carried nitrates down to the aguifer from the land surface. An early snow cover prevented the ground from freezing, and a mild winter allowed recharge to the aquifer in much of the sand-plain area during the winter and early spring. Little rain fell in spring 1983 before samples were collected, so that water levels had not risen much before the spring sampling. What recharge did reach the water table during winter and early spring moved slowly through the soil; this allowed time for the dissolution of nitrates and resulted in the highest mean nitrate concentration ( $17 \mathrm{mg} / \mathrm{L}$ ) observed during the study. The maximum nitrate concentration observed during this study $(72 \mathrm{mg} / \mathrm{L})$ was observed in spring 1983 in a well downgradient from a field that received an application of anhydrous ammonia fertilizer in fall 1982.

During summer 1983, recharge continued to reach the water table, mean water levels rose from 9.65 to 9.23 feet below land surface, and the mean nitrate concentration declined from $17 \mathrm{mg} / \mathrm{L}$ in spring to $14 \mathrm{mg} / \mathrm{L}$ in summer 1983. By fall, nitrates in the soil were depleted by the growth of crops through the summer; although some recharge reached the water table, the mean water level declined from 9.23 to 9.40 feet below land surface. The mean nitrate concentration decreased from 14 to $13 \mathrm{mg} / \mathrm{L}$ by late fall 1983, possibly as the result of denitrification and dilution by the small amount of recharge that did reach the water table.

In spring 1984, recharge from snowmelt and spring rains was large and rapid and resulted in record-high water levels in several long-tarm observation wells in the study area. The mean water level from the 20 wells observed for this study rose to 8.71 feet below land surface. The unusually 
large amount of recharge quickly flushed out soluble nitrates from the soil and, later, as dilute recharge continued to reach the water table, nitrate concentrations in the ground water were reduced to $6.8 \mathrm{mg} / \mathrm{L}$ - - the lowest mean nitrate concentration since before August 1982.

The complexities of fluctuations in nitrate concentrations point out the involved interrelation of factors affecting nitrate in the ground water. Three of the factors that may affect nitrate concentrations in ground water are (1) the rate of movement of recharge through soil and the unsaturated zone, providing more time or less time for solution of nitrates, (2) the volume of recharge, and (3) the timing of fertilizer applications either before, after, or during recharge.

Mean concentrations of nitrite plus nitrate, as shown in table 6 , do not fluctuate nearly as much as concentrations in individual wells. We1ls screened at the water-table in the Sauk River valley show much larger seasonal fluctuations in nitrate than do the deeper wells (fig. 7). In the water-table wells, nitrate concentrations fluctuated between 18 and $72 \mathrm{mg} / \mathrm{L}$ at an irrigated site and between 11 and $54 \mathrm{mg} / \mathrm{L}$ at a nonirrigated cultivated site. At both of these sites with pairs of wells, the nitrate concentration in the deeper wells (34 and 26 feet deep, respectively) fluctuated between less than 0.1 and $0.27 \mathrm{mg} / \mathrm{L}$. The water levels in these wells (fig. 7) generally rose from fall 1982 to spring 1984. At both of these sites, nitrate reached a maximum concentration in May 1983. Although recharge continued to reach the water table, indicated by rising water levels, the nitrate concentration declined in both water-table wells by May 1984 to the lowest concentrations observed. A possible explanation might be that readily soluble nitrates had been leached from the soil, and the rapid infiltration of heavy rainfall passed through the sandy soil too rapidly to dissolve and transport much nitrate.

At the irrigated-well site, the nitrate concentration in the water-table well decreased from $45 \mathrm{mg} / \mathrm{L}$ in November 1983 to $18 \mathrm{mg} / \mathrm{L}$ in May 1984 (fig. 7). Soybeans were planted in the upgradient adjacent field in 1984 instead of corn, which had been planted the preceeding 2 years. Soybeans require less fertilization than corn, and the lack of heavy spring fertilization normally used for corn may have helped make it possible for spring recharge to dilute the nitrate concentration at the water table. However, corn was planted and fertilized immediately upgradient from well 126N3509BAD02 at the nonirrigated cultivated site each year from 1982 to 1984, and nitrate concentrations at that well also declined. Crop rotation may reduce the rate of application of fertilizer periodically and provide an opportunity for denitrification and dilution, which reduce nitrate concentrations in the ground water. Proper evaluation of the effect of crop rotation and of controlling rates and timing of fertilizer application on nitrate concentrations in ground water will require more detailed data than were available in this study. 


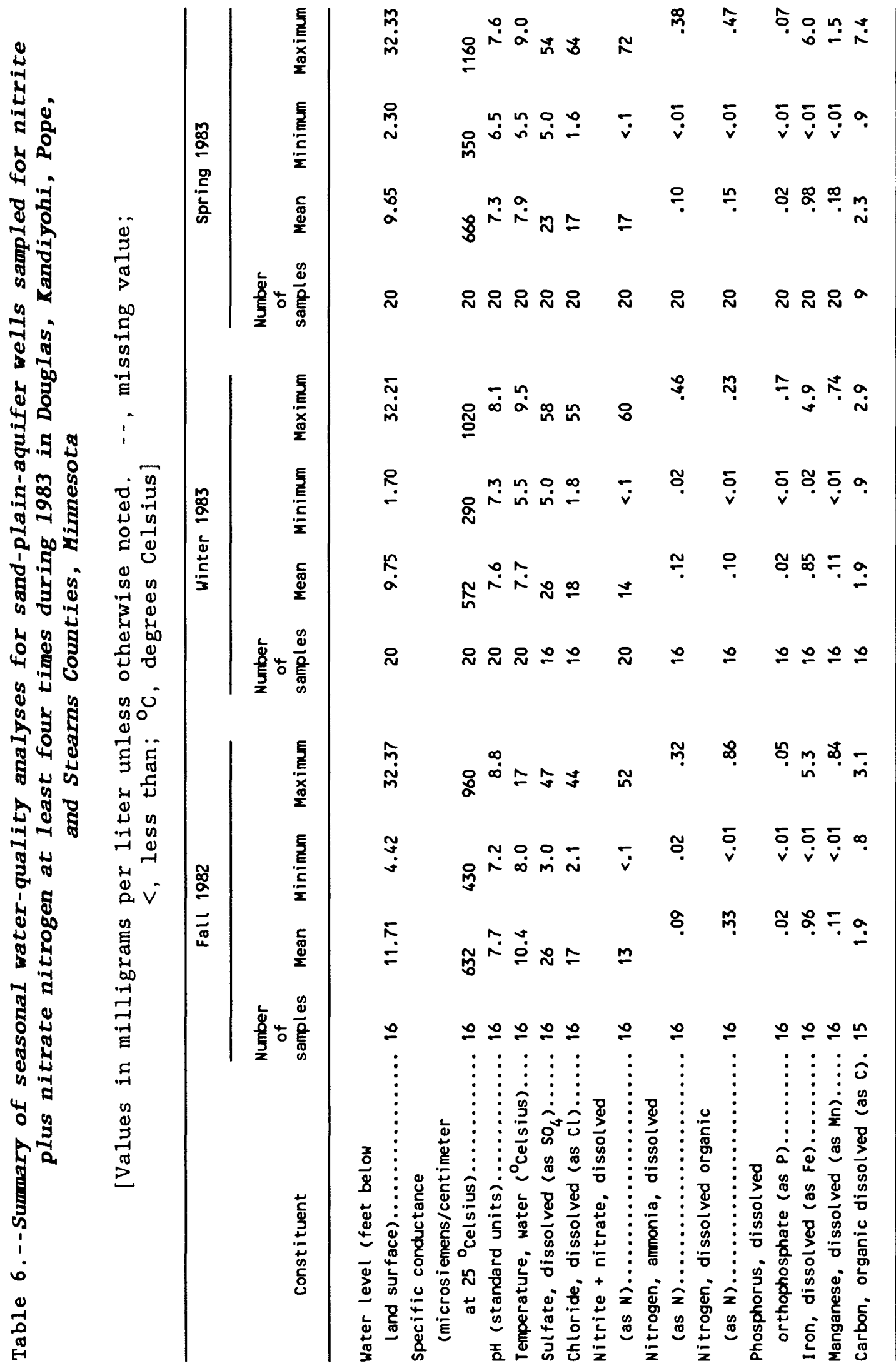




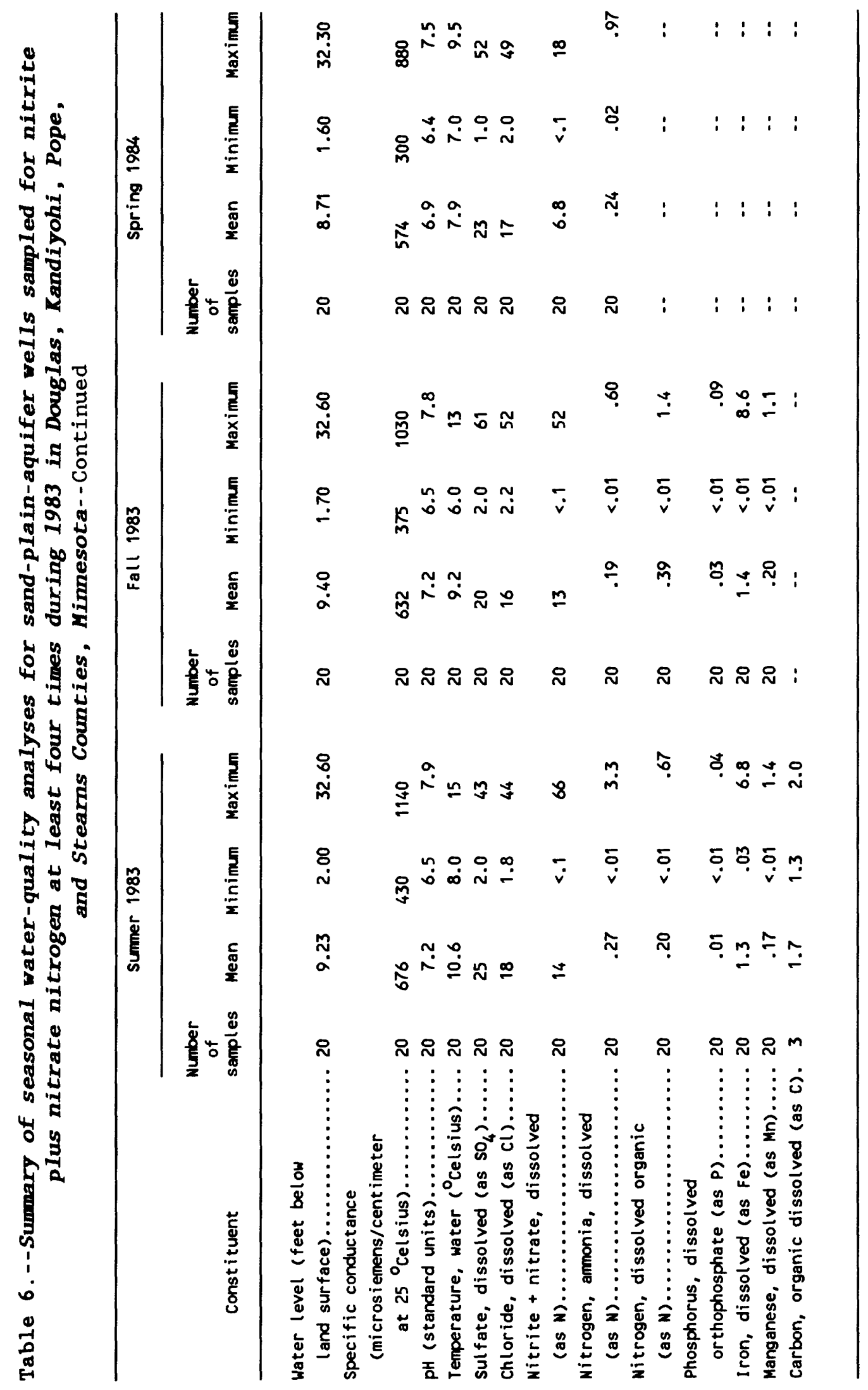


Nitrate concentrations at well sites in the broad Viking Basin and Bonanza Valley aquifers also fluctuated seasonally (fig. 8) but not as much as in water-table wells in the narrow Sauk River valley. The three wells at one site in the Viking Basin, Douglas County (fig. 8), showed that nitrate concentrations in the mid-depth well exceeded concentrations in the deepest well, and the concentration of nitrate in the shallow well approached the concentration in the other two wells. These changes indicate that mixing is taking place in the broad sand-plain aquifers to a greater extent than in the narrow Sauk River valley aquifer (fig. 7). This mixing may account for both the smaller seasonal fluctuation in nitrate concentrations and the smaller differences in concentrations between shallow and deeper wells.

Ammonium concentrations fluctuated during the study, and the high mean concentrations of $0.27 \mathrm{mg} / \mathrm{L}$ in summer 1983 and $0.24 \mathrm{mg} / \mathrm{L}$ in spring 1984 may correlate in time with the application of anhydrous ammonia or other ammonia fertilizers, but the high ammonium concentration in the ground water may be more closely related to denitrification than to ammonia fertilizer. When anhydrous ammonia is applied to a field, it is quickly adsorbed in the soil zone, and, immediately after the anhydrous ammonia is injected into the soil, no ammonia odor can be detected (Gregory C. Buzicky, Minnesota Department of Agriculture, oral commun., 1985). The ammonia may form ammonium ions and be converted to nitrate biochemically. It is unlikely that ammonia would be carried through the oxidizing environment of the unsaturated zone to reach the water table as ammonia or as ammonium ions.

Organic nitrogen decreased from a mean concentration of $0.33 \mathrm{mg} / \mathrm{L}$ in fall 1982 to $0.1 \mathrm{mg} / \mathrm{L}$ in winter 1983 , and then gradually increased to $0.39 \mathrm{mg} / \mathrm{L}$ in fall 1983. The reason for this fluctuation has not been determined.

Little seasonal fluctuation was observed in mean concentrations of sulfate and chloride (table 6); however, seasonal fluctuation in concentrations of these constituents were observed in a number of individual wells. For example, water from a shallow well in the Viking Basin had sulfate concentrations that varied from $23 \mathrm{mg} / \mathrm{L}$ in August 1982 to $42 \mathrm{mg} / \mathrm{L}$ in July 1983 and to $18 \mathrm{mg} / \mathrm{L}$ in November 1983; chloride concentrations varied from $7.6 \mathrm{mg} / \mathrm{L}$ in August 1982 to $21 \mathrm{mg} / \mathrm{L}$ in November 1983 and to $18 \mathrm{mg} / \mathrm{L}$ in May 1984. More information on possible sulfate and chloride sources would be needed in order to interpret the changes that were observed. Sulfate and chloride concentrations are consistently below the Minnesota drinking-water standard of $250 \mathrm{mg} / \mathrm{L}$ for each of these constituents.

Mean concentrations of iron and manganese rose from $0.96 \mathrm{mg} / \mathrm{L}$ in fall 1982 to $1.4 \mathrm{mg} / \mathrm{L}$ in fall 1983, and from $0.11 \mathrm{mg} / \mathrm{L}$ in fall 1982 to $0.20 \mathrm{mg} / \mathrm{L}$ in fall 1983, respectively. The general increase in concentrations may be related to increased recharge to the aquifer. The source of the increased iron and manganese is not known, but may be due to increased solution of iron minerals as recharge percolated through the unsaturated zone to the water table. The data for specific conductance, $\mathrm{pH}$, and in mean concentration of orthophosphate in table 6 shows little seasonal fluctuation. 


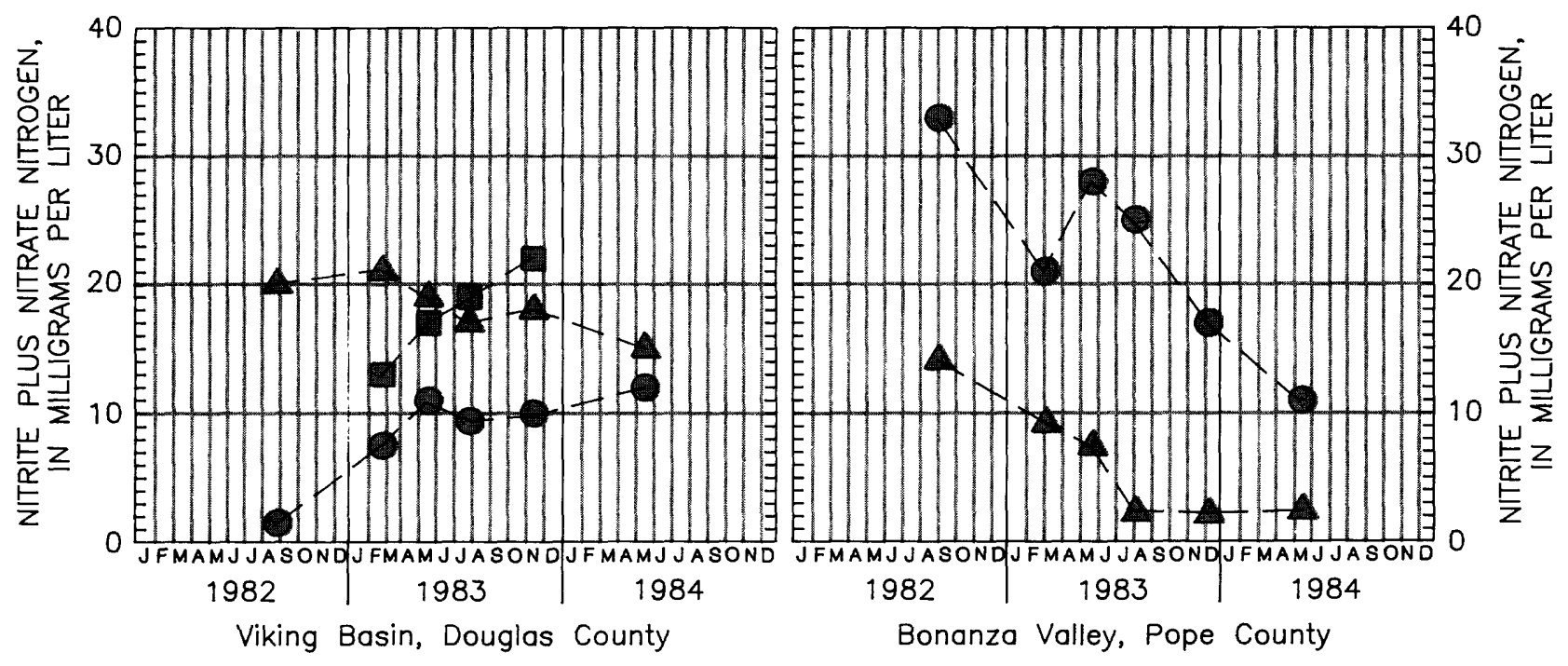

EXPLANATION

Shallow well

Well 129N36W18CBB12, screened

2 to 4 feet below water table

Medium-depth well

Well 129N36W18CBB01, screened

11 to 13 feet below water table

Deeper well

Well 129N36W18CBB11, screened

23 to 25 feet below water table
- Shallow well

Well 123N36W01ACA02, screened

6 to 8 feet below water table

Deeper well

Well 123N36W01ACA01, screened

26 to 28 feet below water table

FIGURE 8.--Seasonal fluctuations in nitrite plus nitrate nitrogen concentrations in wells in irrigated areas of the Viking Basin, Douglas County and the Bonanza Valley, Pope County, Minnesota. 
The amount of seasonal fluctuation in sulfate and chloride concentrations at well sites in irrigated and nonirrigated cultivated areas in the Sauk River valley, as shown in figure 9, is greater than fluctuations in seasonal mean concentrations listed in table 6. As with nitrate, the fluctuations in sulfate and chloride concentrations were more than twice as large in the water-table wells as in the adjacent deeper wells. Iron concentrations in water from these same wells showed large fluctuations (fig. 10) and large differences between water-table and deeper wells. However, the deeper wells have the higher concentration of iron. Manganese concentrations (fig. 11) did not fluctuate much except in the water-table well at the irrigated site.

\section{Long-term Changes In Water Quality}

Long-term changes in water quality were determined by comparing analyses of samples collected from nine wells in fall 1982 to anlayses of samples collected from the same wells in 1965-78. These data indicated a 134-percent increase in the mean concentration of nitrate nitrogen--from 4.7 to $11.0 \mathrm{mg} / \mathrm{L}$. The seasonal fluctuation of nitrate in those same wells was as great or greater than the long-term change. However, the lowest seasonal values of nitrate concentrations in samples from most of the we1ls in 1982-84 were higher than the concentrations in 1965-78.

Two wells completed less than 10 feet below the water table--one a waterlevel-observation well in an uncultivated area and the other a domestic well in a nonirrigated cultivated area--generally had the same nitrate concentration in 1982-83 as they did 10 or more years earlier (fig. 12). Slightly deeper wells, completed 10 to 20 feet below the water table in an unirrigated cultivated area (fig. 13) and in an irrigated area (fig. 14) had nitrate concentrations generally higher in 1983 than 10 or more years earlier. However, the amount of fluctuation during the study is greater than the difference between the lowest recent concentration and the concentration 10 or more years earlier in most of these wells. The historical trend in nitrate concentrations in wells completed more than 20 feet below the water table is slightly upward (fig. 15) but not nearly as much as for wells completed between 10 and 20 feet below the water table. Water in the wells shown in figure 14 already had elevated nitrate concentrations when first sampled in 1968 to 1973. The upward trend might have been more obvious if these wells had been sampled even earlier, before irrigation began.

A long-term increase in nitrate concentrations in the deeper wells may be more representative of water-quality conditions in the sand-plain aquifers. The amount of seasonal fluctuation of nitrate, sulfate, and chloride in deeper wells is noticeably less than in shallower wells, as illustrated in figures 7 and 9. The large amount of short-term or seasonal fluctuation in nitrate concentrations suggests that it might not take very long for nitrate concentrations to be reduced once the source of excess nitrogen is controlled or reduced. 


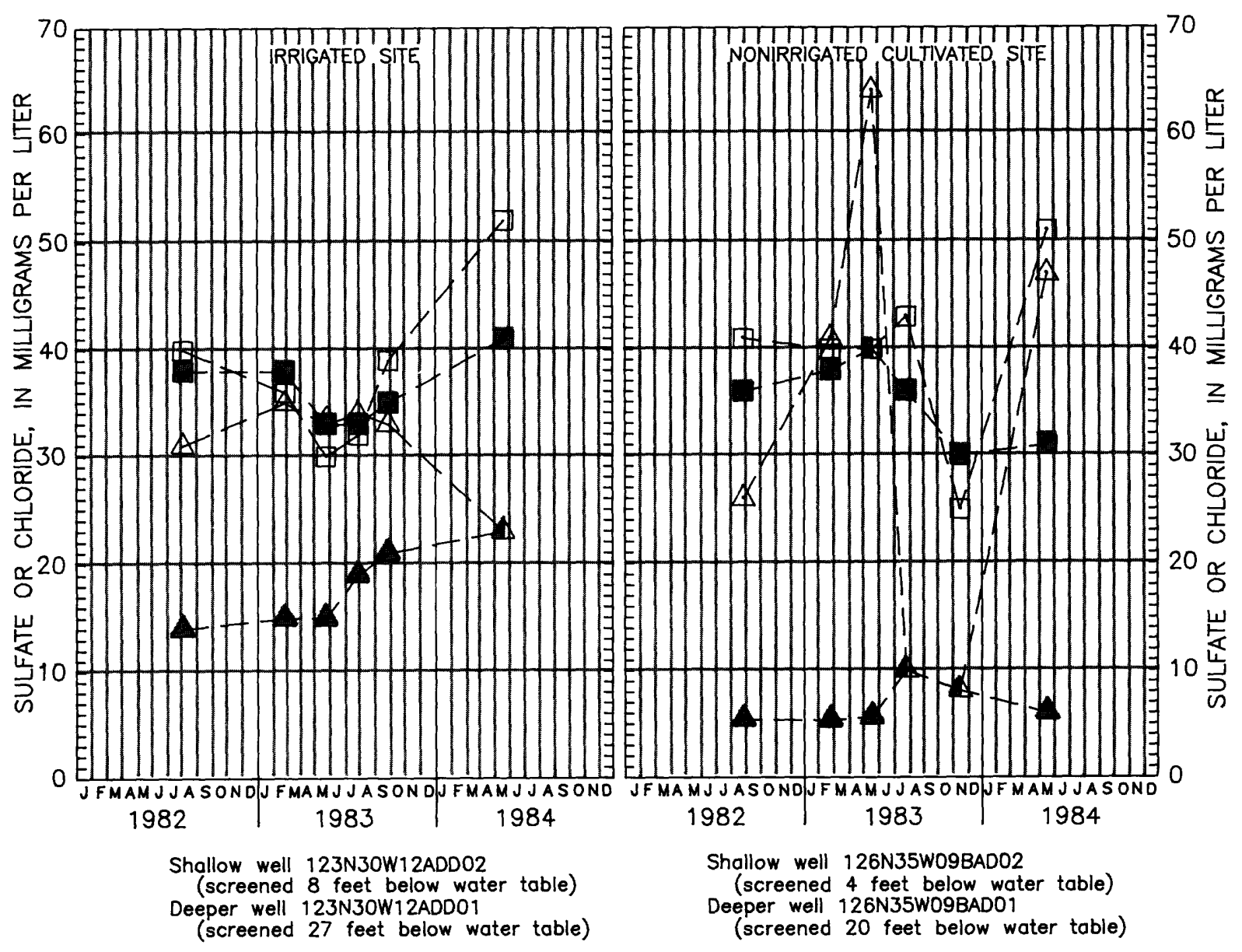

\author{
EXPLANATION \\ Sulfate concentration \\ $\square$ Shallow well \\ Deeper well \\ Chloride concentration \\ $\triangle$ Shallow well
}

FIGURE 9.--Seasonal fluctuations in concentrations of sulfate and chloride at two well sites in the Sauk River valley, Stearns County, Minnesota. 


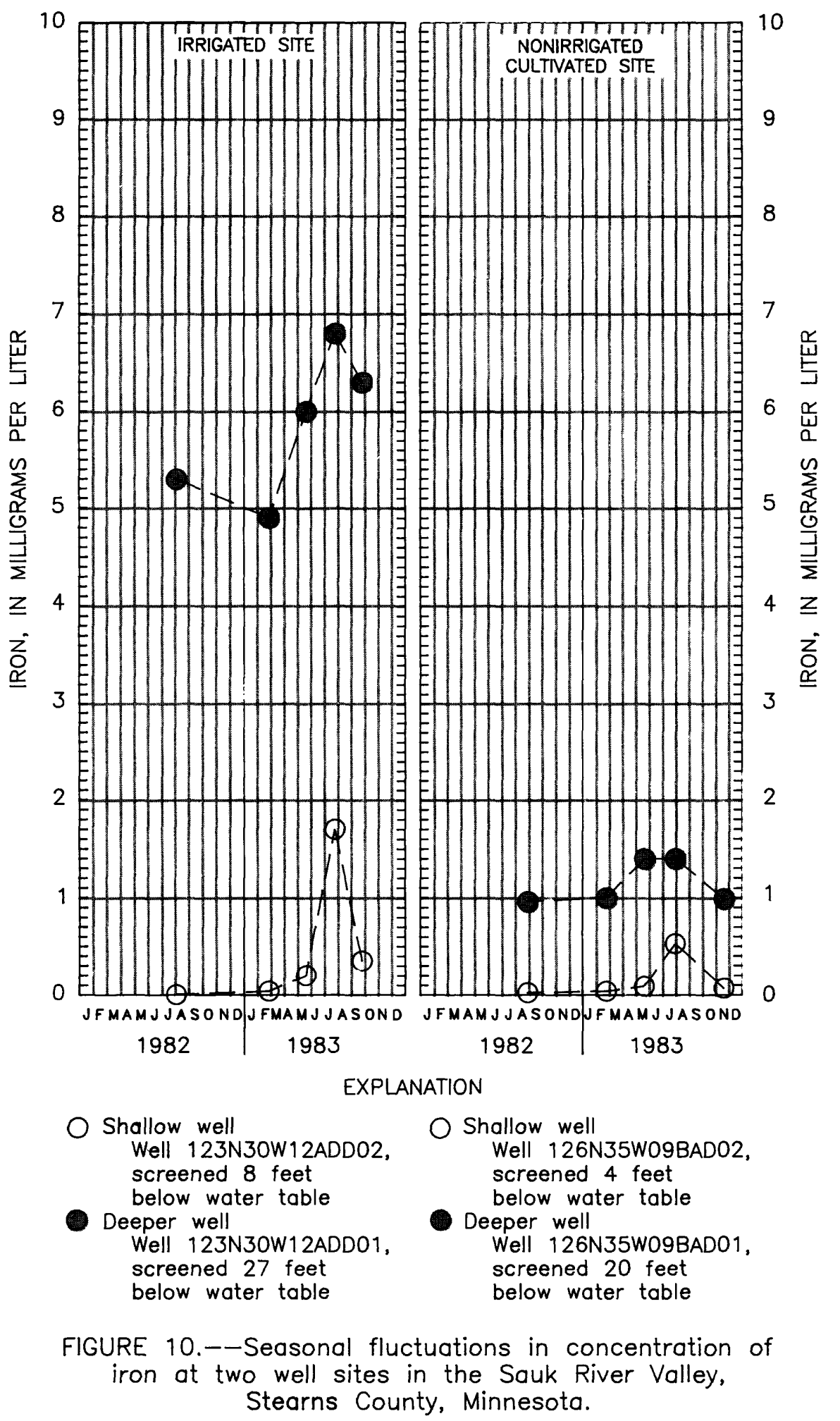




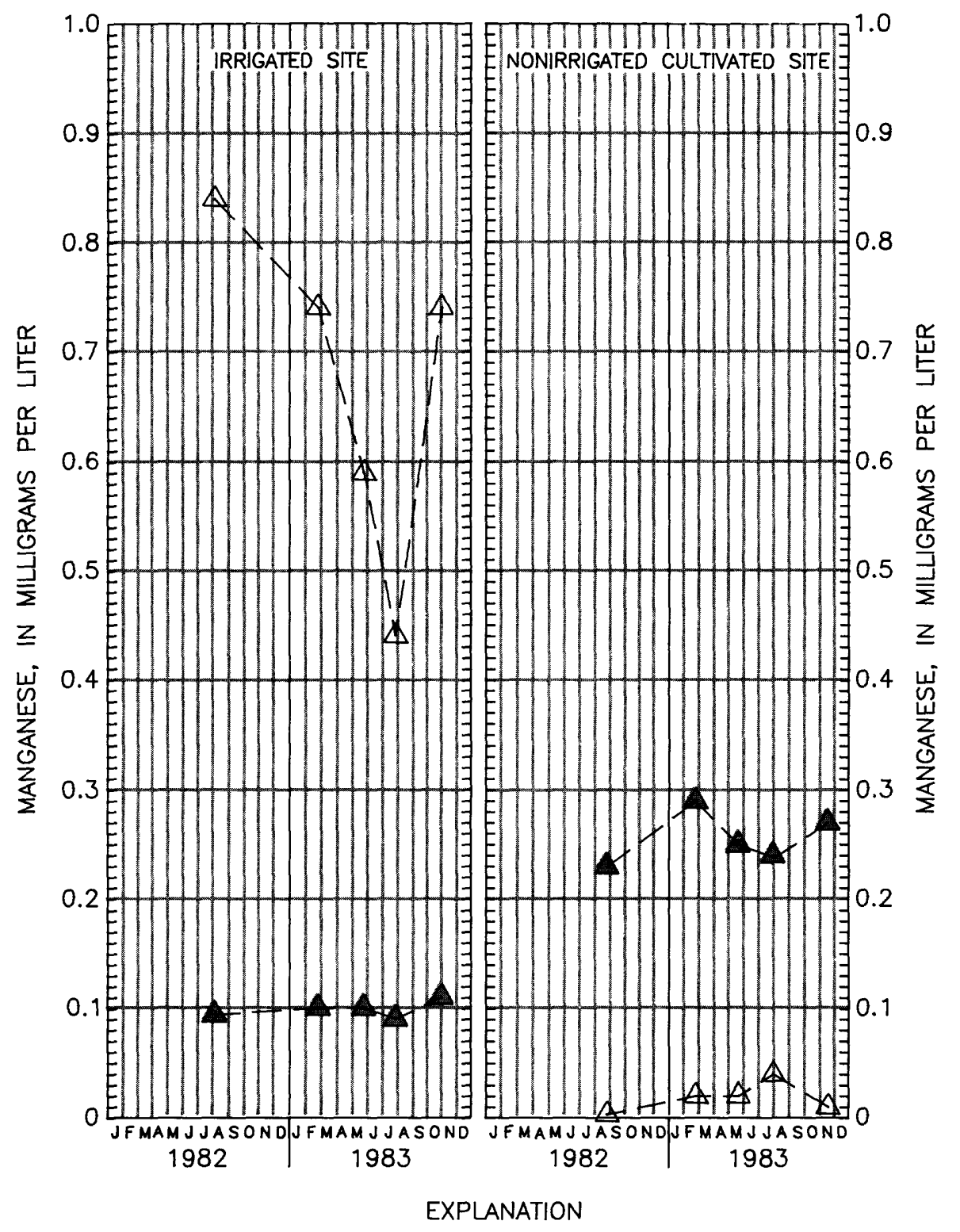
$\triangle$ Shallow well
Well 123N3OW12ADD02, screened 8 feet below water table
$\triangle$ Deeper well
Well 123N30W12ADD01, screened 27 feet below water table
$\triangle$ Shallow well
Well 126N35W09BAD02,
screened 4 feet
below water table
$\Delta$ Deeper well
Well 126N35W09BAD01,
screened 20 feet
below water table

FIGURE 11.--Seasonal fluctuations in concentrations of manganese at two well sites in the Sauk River valley, Stearns County, Minnesota. 




- Uncultivated well site

Well 130N36W04BCC02, screened

3 feet below water table,

Viking Basin, Douglas County

$\triangle$ Nonirrigated cultivated well site

Well 123N34W21DBD02, screened

7 feet below water table,

Bonanza Valley, Stearns County

FIGURE 12.--Historical trends in nitrite plus nitrate nitrogen concentrations in wells less than 10

feet below the water table in uncultivated

and nonirrigated cultivated settings. 


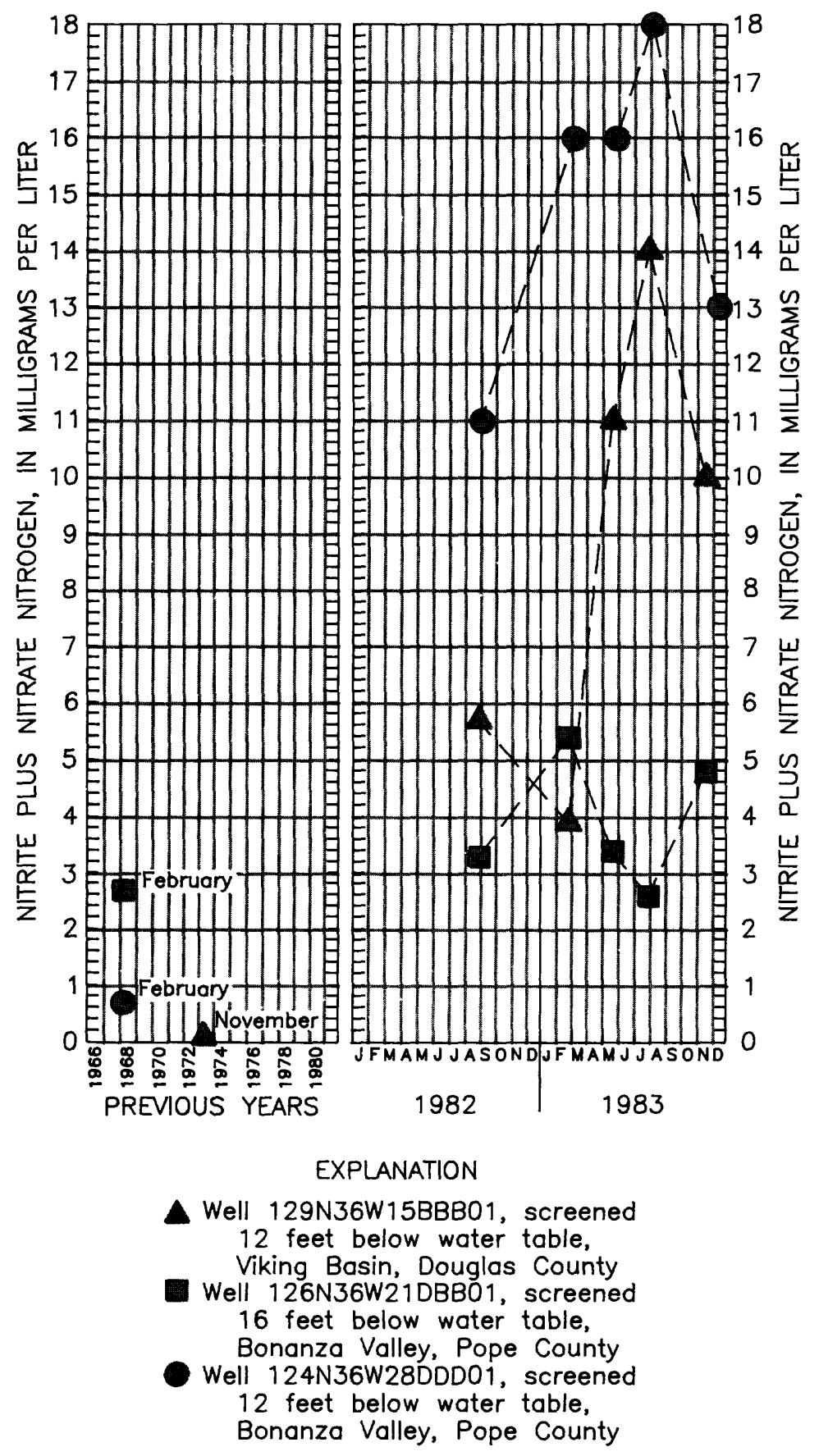

FIGURE 13.--Historical trends in nitrite plus nitrate nitrogen concentrations in wells screened from

10 to 20 feet below the water table in nonirrigated cultivated settings. 




Viking Basin, Douglas County

$\triangle$ Well 129N36W18CBB01, screened 11 feet below water table

- Well 129N37W13ACC01, screened 15 feet below water table

Well 127N37W23DAD02, screened 15 feet below water table Bonanza Valley, Pope County $\nabla$ Well 126N37W34CCC01, screened 12 feet below water table

FIGURE 14.--Historical trends in nitrite plus nitrate nitrogen concentrations in wells completed from 10 to 20 feet below the water table in irrigated settings. 


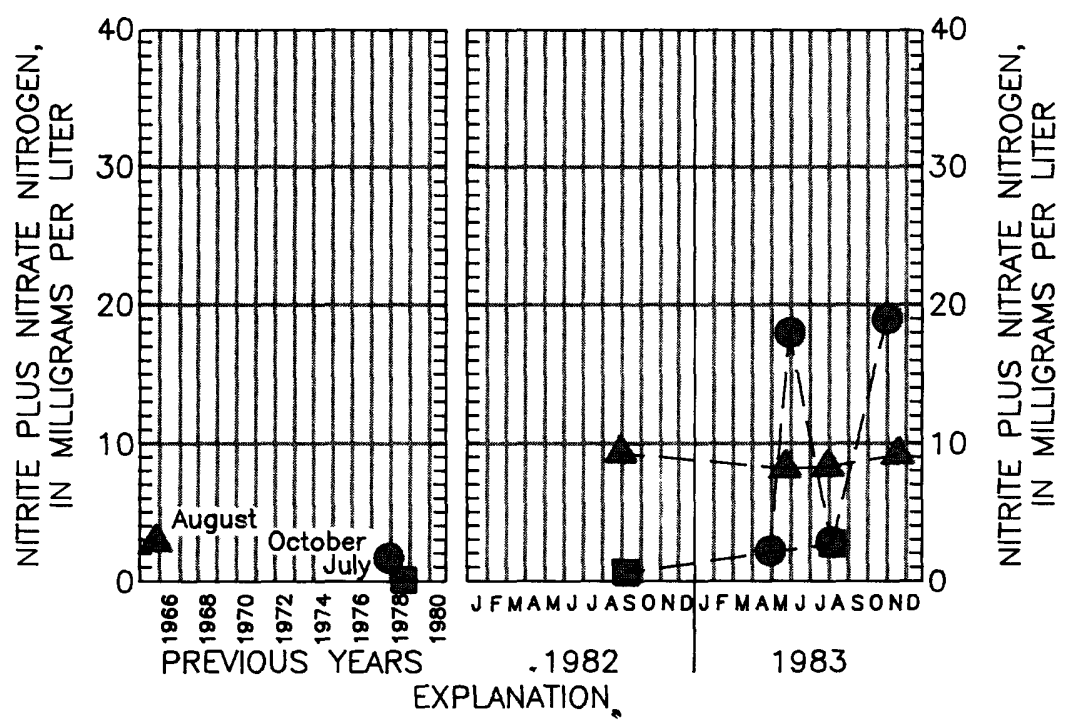

$\Delta$ Well 126N37W35DAD02, screened 26 feet below water table, Bonanza Valley, Pope County

Well 125N33W01CDD01, screened 52 feet below water table, Sauk River Valley, Stearns County - Well 123N31W13AAC04, screened 23 feet below water table, Sauk River Valley, Stearns County

FIGURE 15.--Historical trends in nitrite plus nitrate nitrogen concentrations in wells screened more than 20 feet below the water table in irrigated settings. 


\section{EFFECTS OF AGRICULTURE ON QUALITY OF WATER IN SAND-PLAIN AQUIFERS}

\section{Relation of Water Quality to Land Use}

In order to evaluate the effect of agriculture on the water quality in relation to land-use settings, data from wells in uncultivated areas, nonirrigated cultivated areas, and irrigated areas were compared. The wells representing these different land-use settings were selected to represent maximum impact of one of these land uses and avoid the influence of other land uses. Mean values for sulfate, chloride, nitrate, and organic nitrogen were significantly different for the three land-use settings (table 7). However, the mean dissolved-solids concentrations for the three land-use settings were almost identical and the mean of major cations indicated little difference between land-use settings (table 7). Median values showed even less difference. Ammonia, phosphorus, boron, and fluoride also indicated little or no difference between the three land-use settings.

Concentrations of less than $0.2 \mathrm{mg} / \mathrm{L}$ of nitrate nitrogen have been assumed to represent natural background concentrations (Madison and Brunett, 1985). In the study area, concentrations greater than $3 \mathrm{mg} / \mathrm{L}$ nitrate were assumed to indicate elevated concentrations resulting from human activities. The mean nitrate concentration for wells in uncultivated settings in the project area was $4.4 \mathrm{mg} / \mathrm{L}$ (table 7 ), which suggests that even apparently natural uncultivated settings in the study area have been affected by the introduction of nitrates into the ground-water environment. Nitrate concentrations in irrigated settings were significantly higher than in nonirrigated cultivated and uncultivated settings, based on analysis of variance using Duncan's Multiple Range Test and Tukey's Studentized Range Test. However, nitrate concentrations in nonirrigated cultivated settings and in apparently natural uncultivated settings were not significantly different from each other. This also suggests that water quality in both these settings has been affected similarly, apparently by past agricultural practices.

Well sites selected to represent cultivated land use, either with or without irrigation, were chosen to be as free as possible from the influence of septic systems, cattle yards, and feedlots. The only apparent source of nitrates at these sites is fertilizer applied to fields upgradient from the well site. Elevated nitrate concentrations in the ground water appear to be mostly from fertilizer applied to fields and carried down to the water table by the infiltration of precipitation or irrigation water. Commonly used fertilizers (Shearer and others, 1974, p. 313) include: anhydrous ammonia $\left(\mathrm{NH}_{3}\right)$, ammonium hydroxide $\left(\mathrm{NH}_{4} \mathrm{OH}\right)$, ammonium phosphate [ $\left(\mathrm{NH}_{4}\right)_{2} \mathrm{HPO}_{4}$ ], ammonium sulfate $\left[\left(\mathrm{NH}_{4}\right)_{2} \mathrm{SO}_{4}\right]$, ammonium nitrate $\left(\mathrm{NH}_{4} \mathrm{NO}_{3}\right)$, sodium nitrate $\left(\mathrm{NaNO}_{3}\right)$, potassium nitrate $\left(\mathrm{KNO}_{3}\right)$, urea (an organic compound), potassium chloride $(\mathrm{KCl})$, and animal manure. Human and animal wastes include organic compounds high in nitrogen, chloride, and sulfate. In cultivated areas, both with and without irrigation, increases in sulfate and chloride concentrations are associated with increases in nitrate (table 7), but the sulfate and chloride concentrations are not as high in these areas as downgradient from a feedlot. 


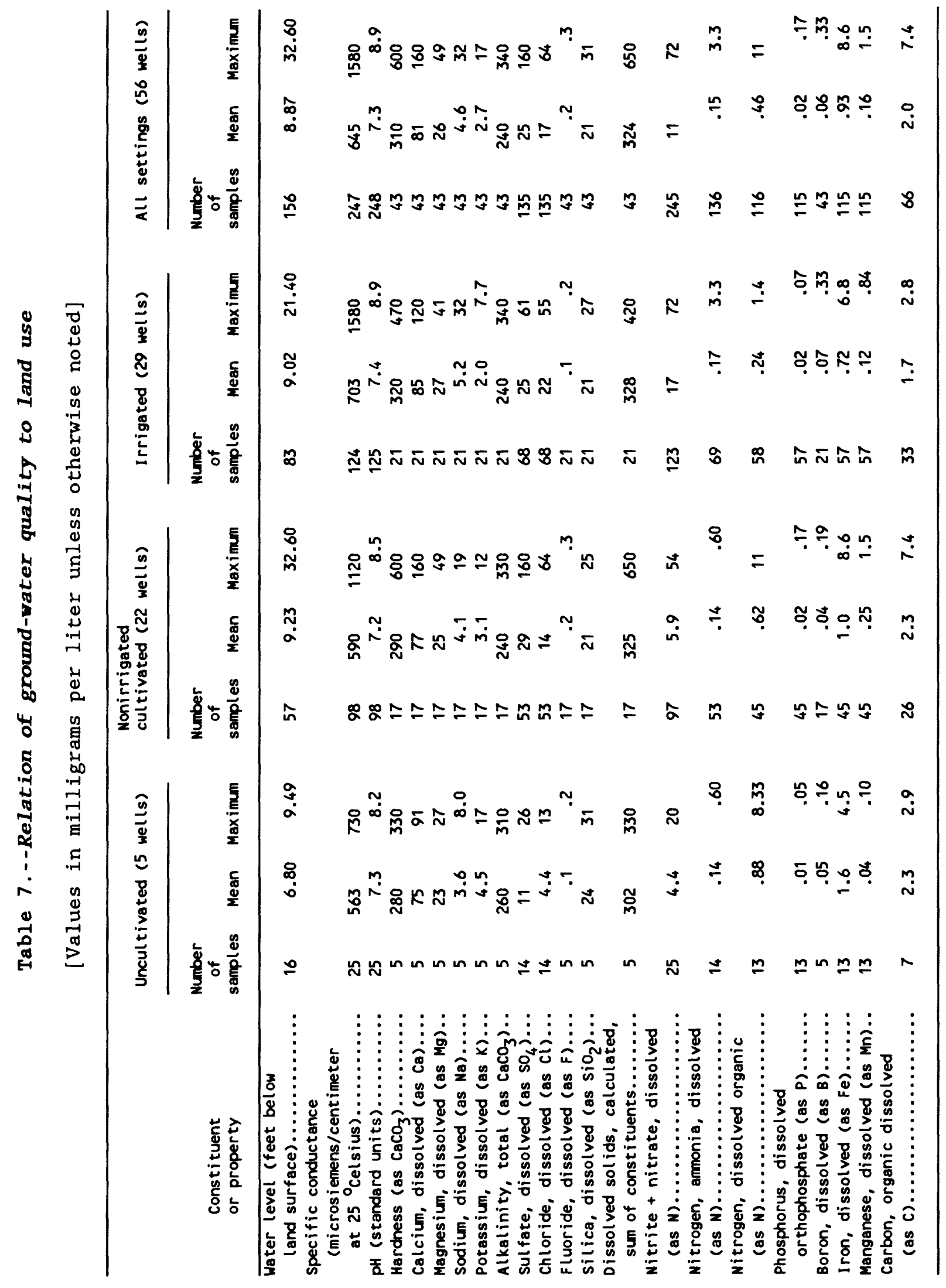


Especially high concentrations of sulfate and chloride, $160 \mathrm{mg} / \mathrm{L}$ and 53 $\mathrm{mg} / \mathrm{L}$, respectively, were found in a sample from a well less than 1 mile downgradient from two feedlots. No nitrate concentrations in samples from this well exceeded $5.8 \mathrm{mg} / \mathrm{L}$, probably because of denitrification that occurred in a marshy area through which the water flows between the feedlots and the well.

The presence of elevated sulfate, chloride, and nitrate concentrations in the same water sample does not clearly identify the source of nitrate in the water. However, in an agricultural setting the absence of elevated chloride and sulfate concentrations and presence of elevated nitrate concentrations does suggest that commerical fertilizer was the source of the nitrate.

Irrigation as a practice seems to affect nitrate pollution. However, in individual instances, a nonirrigated cultivated site may have nitrate concentrations very similar to that at an irrigated site (table 5). Also, the relatively low nitrate concentration in a domestic well completed 12 feet below the water table immediately downgradient from an irrigated area in the Bonanza Valley (fig. 14) shows that irrigation is not necessarily associated with excessively high nitrate. In the past, there has been a tendency for a single large application of nitrogen fertilizer at planting time for crops such as corn and potatoes. Recently, however, many farmers have recognized the advantage of splitting applications of nitrogen fertilizers, applying nitrogen fertilizers at two or more times. This results in increased fertilizer efficiency, reduced costs, and a decreased potential for leaching of nitrate to the ground-water system.

Nitrate concentrations in relation to land-use and well depth below the water table are summarized in table 8 . Nitrate concentrations decrease with depth below the water table in all three land-use settings. These data indicate that an acceptable drinking-water supply, in terms of nitrate concentrations, generally can be developed locally in any of these settings. However, it may be necessary to complete a well at greater depth in an irrigated area to avoid elevated nitrate concentrations

The surficial sand-plain aquifers in the study area are used extensively for domestic water supplies. Elevated nitrate concentrations and contamination by pesticides are two of the more serious agricultural problems affecting the quality of ground water in these aquifers. Large seasonal fluctuations in nitrate concentrations demonstrate that concentrations change rapidly and indicate that problems with elevated concentrations of nitrate might be reduced by reducing the source of nitrate available for infiltration to the water table. This might be accomplished in a relatively short time by modifying agricultural practices. 


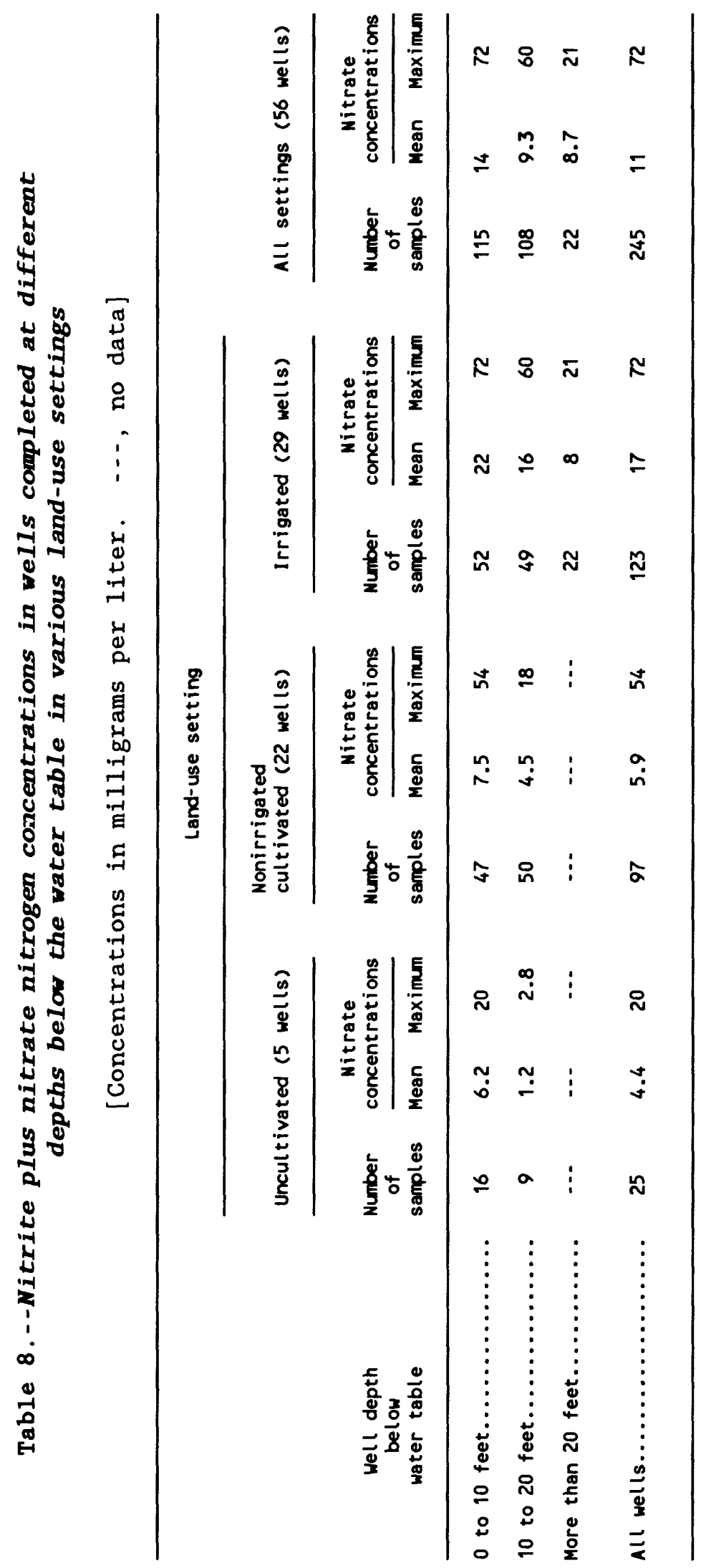




\section{$\underline{\text { Pesticides }}$}

Triazine herbicides are the most widely used pesticides in the four counties of the project area. The five herbicides used in the greatest quantities are alachlor, atrazine, cyprazine, metribuzin, and trifluralin. The carbamate insecticide aldicarb is of special concern because it has been found in ground water in several other states, including Wisconsin, New York, and Florida. Pesticide usage locally includes other insecticides and fungicides, as well as other herbicides, but their use is less common. Therefore, analyses were performed only for those pesticides most likely to be present in the ground water. Samples were analyzed for the triazine herbicide group, including ametriyn, atratone, atrazine, cyanazine, cyprazine, prometone, prometryne, propazine, simazine, simeton, and simetryne. Analyses also were performed for alachlor, metribuzin, and trifluralin.

Three of eight wells sampled for herbicides in summer 1983 had atrazine in concentrations ranging from 0.2 to $0.6 \mu \mathrm{g} / \mathrm{L}$ (micrograms per 1iter). Samples from one of those three wells and from one other well had concentrations of $0.2 \mu \mathrm{g} / \mathrm{L}$ of another triazine-1ike compound that was not specifically identified. When the four wells were resampled in December 1983, water from all four wells contained atrazine and the other triazine-1ike compounds in concentrations that ranged from 0.2 to $0.5 \mu \mathrm{g} / \mathrm{L}$. Samples from three wells were tested for the insecticide aldicarb, but none was detected.

Herbicides were found in water from shallow wells in both irrigated and nonirrigated cultivated areas. In an irrigated setting, one well screened more than 20 feet below the water table and with an elevated nitrate concentration was sampled for herbicides, but none were detected. Triazine herbicides were found in shallow wells in one out of three wells in nonirrigated cultivated settings and in three out of four wells in irrigated settings.

The presence of pesticides in ground water is potentially far more serious than high nitrate concentrations because much less is known about the occurrence and persistence of pesticides in ground water. The most heavily used herbicide was alachlor, which was not detected in any of the samples. Present concentrations of herbicides in the study area were observed at levels from 0.1 to $0.6 \mu \mathrm{g} / \mathrm{L}$, which is less than concentrations presently recognized as dangerous for drinking water. The USEPA and the National Academy of Science each have proposed safe limits for a few triazine herbicides, including $150 \mu \mathrm{g} / \mathrm{L}$ for atrazine (David Dally, Minnesota Department of Agriculture Agronomy Services Division, written commun., 1984). Water-quality guidelines published by the Canadian Inland Waters Directorate, Water Quality Branch (McNeely and others, 1979, table 4) specify $100 \mu \mathrm{g} / \mathrm{L}$ as the maximum permissibly concentration for the group of triazine herbicides in a raw drinking-water supply. Although the herbicide concentrations observed are much less than maximum permissible concentrations, the data collected do not rule out possibly serious problems. 
Presently, water-quality data are inadequate to characterize water quality in most aquifers at a scale comparable to that of the land uses that may be affecting water quality. The present study has provided information on the relation between water quality and use of agricultural chemicals, but continued monitoring of future changes in water quality is needed, especially if the effects of new agricultural practices are to be assessed. Indicator constituents that might be important to monitor include sulfate, chloride, nitrate, ammonia and triazine herbicides. Field measurements include water level, specific conductance, $\mathrm{pH}$, water temperature, and alkalinity.

Annual sampling soon after spring snowmelt and recharge was suggested as a sampling time that would produce results that indicate long-term maximum values. Samples collected in late summer or in fall may be more useful in analyzing trends in water quality than samples collected in early spring.

Table 9 is a list of wells proposed for long-term sampling by county, representative of land-use settings, well depths, and areally distributed aquifers discussed in this report. This list was prepared in response to the last of the five objectives stated for this study.

Modifications in agricultural practices, such as minimum tillage; crop rotation; changes in fertilizer-application times, rates, and methods; and pesticide application, need to be studied in more detail to determine their effect on water quality in surficial sand-plain aquifers. The practice of minimum tillage and the application of fertilizer at a carefully selected optimum rate for plant use may result in lower concentrations of nitrate nitrogen in the ground water (H. K. Anderson, Soil and Water Conservation Board, oral commun., 1984), but minimum-tillage practices may increase the use of herbicides and insecticides. Monitoring of water quality is desirable to demonstrate the benefits of these management techniques. Crop rotation, such as a change from corn to soybeans, may reduce periodically the need for fertilizer applications and provide an opportunity for denitrification and dilution to reduce nitrate concentrations.

A clearer understanding of ground-water flow and mixing of ground water could be obtained by age-dating the water at the water table and at depth. Age-dating could be done by tritium analysis and/or by carbon-14 dating. This could also indicate whether or not ground water at depth represents natural background conditions. The uncertainties of the age-dating methods would need to be considered in any project proposal dealing with these methods.

This report describes large vertical differences in nitrate concentrations--72 mg/L in water from a well completed at the water table and $0.27 \mathrm{mg} / \mathrm{L}$ nitrate in water from a well completed only 19 feet deeper at the same site. Horizontal differences on a similar scale were not determined. A detailed study of three dimensional variations in nitrate concentrations could reveal new insights into ground-water quality related to agricultural practices. 
Table 9.--Wells selected for long-term annual sampling of indicator water-quality constituents

\begin{tabular}{|c|c|c|c|c|c|}
\hline \multirow[b]{2}{*}{ County } & \multirow[b]{2}{*}{ We11 number } & \multirow[b]{2}{*}{ Area } & \multirow[b]{2}{*}{$\begin{array}{l}\text { Land-use } \\
\text { setting }\end{array}$} & \multicolumn{2}{|c|}{ We11 depth below: } \\
\hline & & & & $\begin{array}{c}\text { Land surface } \\
\text { (feet) }\end{array}$ & $\begin{array}{l}\text { Water table } \\
\text { (feet) }\end{array}$ \\
\hline \multirow[t]{5}{*}{ Douglas } & 129N36W09BBB01 & Viking Basin & Cultivated & 19 & 15 \\
\hline & 129N36W09BBB01 & Viking Basin & Cultivated & 7 & 3 \\
\hline & 129N36W18CBB11 & Viking Basin & Irrigated & 31 & 23 \\
\hline & 129N36W18DBB12 & Viking Basin & Irrigated & 10 & 2 \\
\hline & 130N36W04BCC02 & Viking Basin & Natural & 7 & 3 \\
\hline \multirow{4}{*}{ Kandiyohi } & 122N34W29BCB01 & Bonanza Valley & Irrigated & 20 & 15 \\
\hline & 122N34W29BCB02 & Bonanza Valley & Irrigated & 9 & 4 \\
\hline & 122N35W14AAB01 & Bonanza Valley & Cultivated & 22 & 20 \\
\hline & $122 \mathrm{~N} 35 \mathrm{~W} 14 \mathrm{AAB} 02$ & Bonanza Valley & Cultivated & 9 & 7 \\
\hline \multirow[t]{5}{*}{ Pope } & 123N36W01ACA01 & Bonanza Valley & Irrigated & 37 & 26 \\
\hline & 123N36W01ACA02 & Bonanza Valley & Irrigated & 16 & 6 \\
\hline & 125N36W04ADA02 & Bonanza Valley & Irrigated & 18 & 10 \\
\hline & 125N37W15ABB01 & Bonanza Valley & Cultivated & 55 & 23 \\
\hline & 125N37W15ABB02 & Bonanza Valley & Cultivated & 33 & 8 \\
\hline \multirow[t]{6}{*}{ Stearns } & 123N30W12ADD01 & Sauk River valley & Irrigated & 34 & 27 \\
\hline & 123N30W23ADD02 & Sauk River valley & Irrigated & 15 & 8 \\
\hline & 123N35W17ADC01 & Bonanza Valley & Irrigated & 30 & 14 \\
\hline & 123N35W17ADC02 & Bonanza Valley & Irrigated & 21 & 5 \\
\hline & 126N35W09BAD01 & Sauk River valley & Cultivated & 26 & 20 \\
\hline & 126N35W09BAD02 & Sauk River valley & Cultivated & 10 & 4 \\
\hline
\end{tabular}




\section{CONCLUSIONS}

Ranges in concentrations of sulfate, chloride, and nitrate were large, but there was little difference in the concentration of most chemical constituents in water from the surficial sand-plain aquifers in the study area--the Bonanza Valley, the Viking Basin, and the Sauk River valley. Concentrations of iron and manganese locally were elevated, but are naturally occurring. Nitrate, chloride, and sulfate concentrations appear to be related to agricultural practices.

Differences in specific conductance and in concentrations of sulfate, chloride, and nitrate with depth below the water table occur at 11 paired-well sites at which one well is screened near the water table and a second well is 10 or more feet deeper. Concentrations generally were greater near the water table. These vertical differences in water quality within the aquifer indicate that, in some areas, particularly in the Sauk River valley, vertical mixing of water is not occuring or is limited.

Deeper wells in the broad sand plains (Bonanza Valley and Viking Basin) had higher nitrate concentrations than deep wells in the narrow Sauk River valley, and differences in concentrations were smaller, possibly indicating more vertical mixing of ground water in the broad sand plains because of localized changes in configuration of the water table.

Seasonal fluctuations in water quality are related to the rate and timing of recharge and fertilizer applications. Mean nitrate nitrogen concentrations rose from $13 \mathrm{mg} / \mathrm{L}$ in fall 1982 to $14 \mathrm{mg} / \mathrm{L}$ in winter 1983 as recharge carried nitrates from land surface to the water table. A small amount of recharge in spring 1983 resulted in an increase in the mean nitrate concentration to 17 $\mathrm{mg} / \mathrm{L}$. In spring 1984, recharge from snowmelt and spring rains was large, resulting in several record-high water levels in the study area. This unusually large amount of recharge flushed soluble nitrates from the soil quickly, and, later, as dilute recharge continued to reach the water table, nitrate concentrations in the ground water were diluted to $6.8 \mathrm{mg} / \mathrm{L}--$ the lowest mean nitrate concentration during the study.

Sulfate and chloride concentrations fluctuated seasonally in some individual wells, but seasonal mean concentrations of sulfate and chloride did not show any substantial general fluctuation. Concentrations of sulfate and chloride are consistently below the Minnesota drinking-water standard of 250 $\mathrm{mg} / \mathrm{L}$ for each of these constituents.

A comparison of nitrate concentrations from samples collected in fall 1982 and samples collected from the same wells 10 or more years earlier (mostly in the fall), showed that the mean concentration increased from 4.7 to $11.0 \mathrm{mg} / \mathrm{L}-\mathrm{-a} 134$-percent increase. However, seasonal sampling through spring 1984 showed that seasonal fluctuations of nitrate in most wells were as great or greater than the long-term change, indicating that seasonal fluctuations in concentration may account for some of the apparent long-term change. However, the lowest nitrate concentrations in most wells sampled during this study were higher than the concentrations 10 to 18 years earlier. 
The difference in nitrate concentrations for irrigated and nonirrigated sites was statistically significant at the 95-percent level. This indicates that irrigated crop production has a significant effect on the concentration of nitrate in ground water (mean nitrate concentration for nonirrigated cultivated areas and irrigated areas are 5.9 and $17 \mathrm{mg} / \mathrm{L}$ respectively). However, the large seasonal fluctuations in nitrate concentrations in several wells, and the presence of several wells in irrigated settings with nitrate concentrations less than $10 \mathrm{mg} / \mathrm{L}$, suggest that excessive nitrate concentrations can be reduced if the source of excess nitrates is controlled, even in irrigated settings. A mean nitrate concentration of $4.4 \mathrm{mg} / \mathrm{L}$ in water from wells in uncultivated areas indicates that nitrate levels may be affected by agriculture even in apparently natural, uncultivated settings.

Triazine herbicides were present in water from four of eight wells sampled. However, herbicides concentrations were well below commonly recognized safe levels for drinking water. More study of the occurrence, distribution, and changes in concentration of pesticides is needed to evaluate the extent of ground-water contamination by these organic compounds. 


\section{REFERENCES CITED}

Edmunds, W. M., 1973, Trace element variations across an oxidation-reduction barrier in a limestone aquifer: Proceedings symposium Hydrogeochem. Biochem., Tokyo 1970, The Clarke Company, Washington, D.C., p. 500-526.

Freeze, R. A., and Cherry, J. A., 1979, Groundwater: Prentice-Hall, New Jersey, $556 \mathrm{p}$.

Freeze, R. A. and Witherspoon, P. A., 1967, Theoretical analysis of regional groundwater flow: 2. Effect of water-table configuration and subsurface permeability variation: Water Resources Res., 3, p. 623-634.

Gillham, R. W., and Cherry, J. A., 1978, Field evidence of denitrification in shallow groundwater flow systems: Proceedings 13 th Canadian Symposium Water Pollution Research, McMasters University, Hamilton, Ontario.

Hem, J. D., 1959, Study and interpretation of the chemical characteristics of natural water: U.S. Geological Survey Water-Supply Paper 1473, 269 p.

Lindholm, G. F., 1980, Ground-water appraisal in Benton, Sherburne, Stearns, and Wright Counties, central Minnesota: U.S. Geological Survey WaterResources Investigations 80-1285, $103 \mathrm{p}$.

Maclay, R. W., Winter, T. C., and Bidwell, L. E., 1968, Water resources of the Mustinka and Bois de Sioux Rivers watershed, west-central Minnesota: U.S. Geological Survey Hydrologic Investivations Atlas HA-272, 4 sheets.

Madison, R. J., and Brunett, J. 0., 1985, Overview of the occurrence of nitrate in ground water of the United States in U.S. Geological Survey, National Water Summary 1984: U.S. Geological Survey Water-Supply Paper 2275, p. $93-105$.

McBride, M. S., 1975, Ground water for irrigation in the Viking Basin, westcentral Minnesota: U.S. Geological Survey Water-Resources Investigations 75$23,48 \mathrm{p}$.

McNeely, R. N., Neimanis, V. P., and Dwyer, L., 1979, Water quality sourcebook, a guide to water quality parameters: Inland Waters Directorate, Water Quality Branch, Ottawa, Canada.

Minnesota Pollution Control Agency, 1978, Minnesota State regulations; rules, regulations, classification, and water standards: Minnesota Pollution Control Agency, Division of Water Quality, $150 \mathrm{p}$.

Myette, C. F., 1984, Ground-water-quality appraisal of sand-plain aquifers in Hubbard, Morrison, Otter Tail, and Wadena Counties, Minnesota: U.S. Geological Survey Water-Resources Investigations Report 84-4080, 49 p.

Rainwater, F. H., and Thatcher, L. L., 1960, Methods for collection and analysis of water samples: U.S. Geological Survey Water-Supply Paper 1454, $301 \mathrm{p}$.

Shearer, G. B., Koh1, D. H., and Commoner, B., 1974, The precision of determinations of the natural abundance of nitrogen-15 in soils, fertilizers, and shelf chemicals: Soil Science, v. 118, no. 5, p. 308-316.

Skougstad, M. W., Fishman, M. J., Friedman, L. C., Erdmann, D. E., and Duncan, S. S., 1979, Methods of analysis of inorganic substances in water and fluvial sediments: U.S. Geological Survey Techniques of Water-Resources Investigations, Book 5, Chapter A1, 1,006 p. 
U.S. Environmental Protection Agency, 1977, Quality criteria for water, 1976: U.S. Environmental Protection Agency, Ecological Research Series, 256 p.

Van Voast, W. A., 1971, Ground water for irrigation in the Brooten-Belgrade area, west-central Minnesota: U.S. Geological Survey Water-Supply Paper $1899-\mathrm{E}, 24 \mathrm{p}$.

Wershaw, R. L., Fishman, M. J., Grabbe, R. R., and Lowe, L. E., Editors, 1983, Methods for the determination of organic substances in water and fluvial sediments: U.S. Geological Survey Techniques of Water-Resources Investigations, Book 5 Laboratory Analysis, Chapter A3, $173 \mathrm{p}$.

Wright, H. E., Jr., Ruhe, R. V., 1965, Glaciation of Minnesota and Iowa in Wright, H. E., Jr., and Frey, D. G., eds., The Quaternary of the United States: Princeton University Press, Princeton, New Jersey, p. 29-41. 